\title{
One Danger and Eleven Types of Academic Disquiet Whilst Hunting for Cinematic Christ-figures
}

\author{
Anton Karl Kozlovic \\ Researcher in Department of Media and Communication, Deakin University, Victoria, \\ Australia.Email Id: akozlovi@deakin.edu.au
}

\begin{abstract}
Christ-figures increasingly permeate the popular cinema, but hunting for them is not necessarily a benign or unproblematic activity. Following a selective review of the film and religion literature, and a preliminary scan of the popular cinema utilizing textually-based humanist film criticism as the guiding analytical lens, one danger and eleven types of academic disquiet were explicated herein. Namely: (1) When Factual Minimalism Equals Certainty: Holy Hope, (2) Misidentification: When Something Supposedly "Christian" Was Something Else, (3) When Nothing Equals Something: Creatio Ex Nihilo, (4) Spiritually Negating Christian Iconography: Form Versus Substance, (5) Some Problems with the Secular-is-Sacred Argument, (6) Film is Not a Substitute for Faith, Religion, or God, (7) Rewriting the Film: Aesthetic Violence?, (8) Tenuous Links, Strained Associations, and Uncertain Correspondences, (9) Rejecting Overt Religion for Covert Religion: Distorting Theology and Misdirecting Faith?, (10) From Symbolism Fatigue to Symbolism Cynicism, and (11) Pattern Appeasement: From Being Uncritical to Narrative Insights. It was concluded that being cognizant of the inherent dangers and sources of academic disquiet is a valuable means of expanding one's visual and intellectual imagination, and also useful for the postmodern church. Further research into the subtextual sub-genre of the religion-and-film field was encouraged, warmly recommended, and is already long overdue.
\end{abstract}

Keywords: Christ-figure, religion-and-film, sacred subtexts, Jesus Christ

Once the bread-and-butter of Bible and film scholarship, Christ-figure analysis remain popular...Most critically, Christ-figure interpretations make Jesus Christ too important. They make Jesus Christ into the standard by which characters and films are evaluated (Seesengood \& Walsh, 2018, p. 248).

\section{Introduction}

Cinematic Christ-figures ${ }^{\mathrm{i}}$ are examples of religious infranarration (aka holy subtexts; sacred subtexts) alternatively described as "anonymous religiousness" (Gallagher, 1997, p. 151) or the pursuit of "overtly religious themes in a secular "wrapper" (Ellis, 2001, p. 304), but with Lesley Brill (1988, p. 104) condescendingly claiming: "Searching out "Christ figures" has become, with some justification, a disreputable pastime among modern critics" [my emphasis]. Nowadays, this claim is rejected because both religion scholars and film scholars have elevated this "pastime" into a reputable sub-genre of the religion-and-film field (aka sacred cinema, spiritual cinema, holy film, cinematic theology, cinematheology, theo-film, celluloid religion, film-and-faith, film-faith dialogue) which has grown from a critic's fancy to an entrenched cottage industry to a fully-

(C) AesthetixMS 2020. This Open Access article is published under a Creative Commons Attribution Non-Commercial 4.o International License (http://creativecommons.org/licenses/by-nc/4.o/), which permits non-commercial re-use, distribution, and reproduction in any medium, provided the original work is properly cited. For citation use the DOI. For commercial re-use, please contact editor@rupkatha.com. 
fledged field of academic discourse that is ever-growing in range, depth, and complexity (Ardolino, 1995; Baugh, 1997; Beavis, 2010; Bechtold, 2015; Deacy, 1999; Frost, 2019; Geck, 2020; Hurley, 1982; Kozloff, 1981; Kozlovic, 2004, 2005, 2016; Malone, 1988, 2012; McEver, 1998; Ortiz, 1994; Peavy, 1974; Reinhartz, 2008, 2011; Ruppersburg, 1987; Scully, 1997; Short, 1983; Telford, 2000; Walsh, 2013). Such scholarship being spurred on by the types of concerns articulated by Father Lloyd Baugh (1997) concerning the scant attention devoted to analysing:

...precisely the concept of the filmic Christ-figure. Just how does it function? What dynamic takes place in the viewing audience as they experience the protagonists of one of these films, a dynamic which allows them to make both identifications and distinctions between the metaphor, the concrete and specific Christ-figure, and the transcendent reality it points to, the Christ figured? (p. 235).

In addition to revealing the deeper intricacies of Christ-figure construction (Kozlovic, 2004, 2005), and tackling other important questions concerning the sacramental nature of cinema (Balstrup, 2020; Knauss, 2020; Marsh, 2005), contemporary “Christian symbol hunters" (Blake, 1996, p. 33) will repeatedly encounter one or more potential problems whilst exploring subtle iconographies, subliminal allusions, and vague Christomorphic resonances that can be "very difficult to define. Like ghosts in the night or faces in the clouds, you can often imagine that you are seeing them, when they are in fact not really there" (Telford, 2000, p. 35). But when Christfigures are there, as a modern-day media modus vivendi, their discovery will feel akin to "The Prayer of St. Patrick" (aka "St Patrick's Breastplate") namely:

Christ be with me,

Christ within me,

Christ behind me,

Christ before me,

Christ beside me,

Christ to win me,

Christ to comfort and restore me,

Christ beneath me,

Christ above me,

Christ in quiet,

Christ in danger,

Christ in hearts of all that love me,

Christ in mouth of friend and stranger (McEntyre, 2012, p. 10).

Indeed, a rough cinematic exemplar of this prayerful declaration dedicated to Jesus Christ was humorously depicted in the spoof film about Mormons, Orgazmo (1997), starring Joseph "Joe" Young (Trey Parker), a financially struggling Mormon missionary needing marriage money, and so accepted a job as a film stunt cock-cum-porn star, Orgazmo. When Joe’s strict Mormon fiancé Lisa (Robyn Lynne) visits a local video shop she browses through the following biblical titles displayed therein (in sequential order): ii (a) Birth of Jesus, (b) Jesus of Nazareth, (c) Jesus the Healer, (d) a psychedelic version of Jesus of Nazareth, (e) Jesus Scissorhands (parodying Edward Scissorhands [1990]), (f) Pulp Jesus (parodying Pulp Fiction [1994]), (g) The Good, The Bad, Jesus 
(parodying The Good, the Bad, and the Ugly [1966]), and (h) Raging Jesus (parodying Raging Bull [1980]) (see Figure 1).
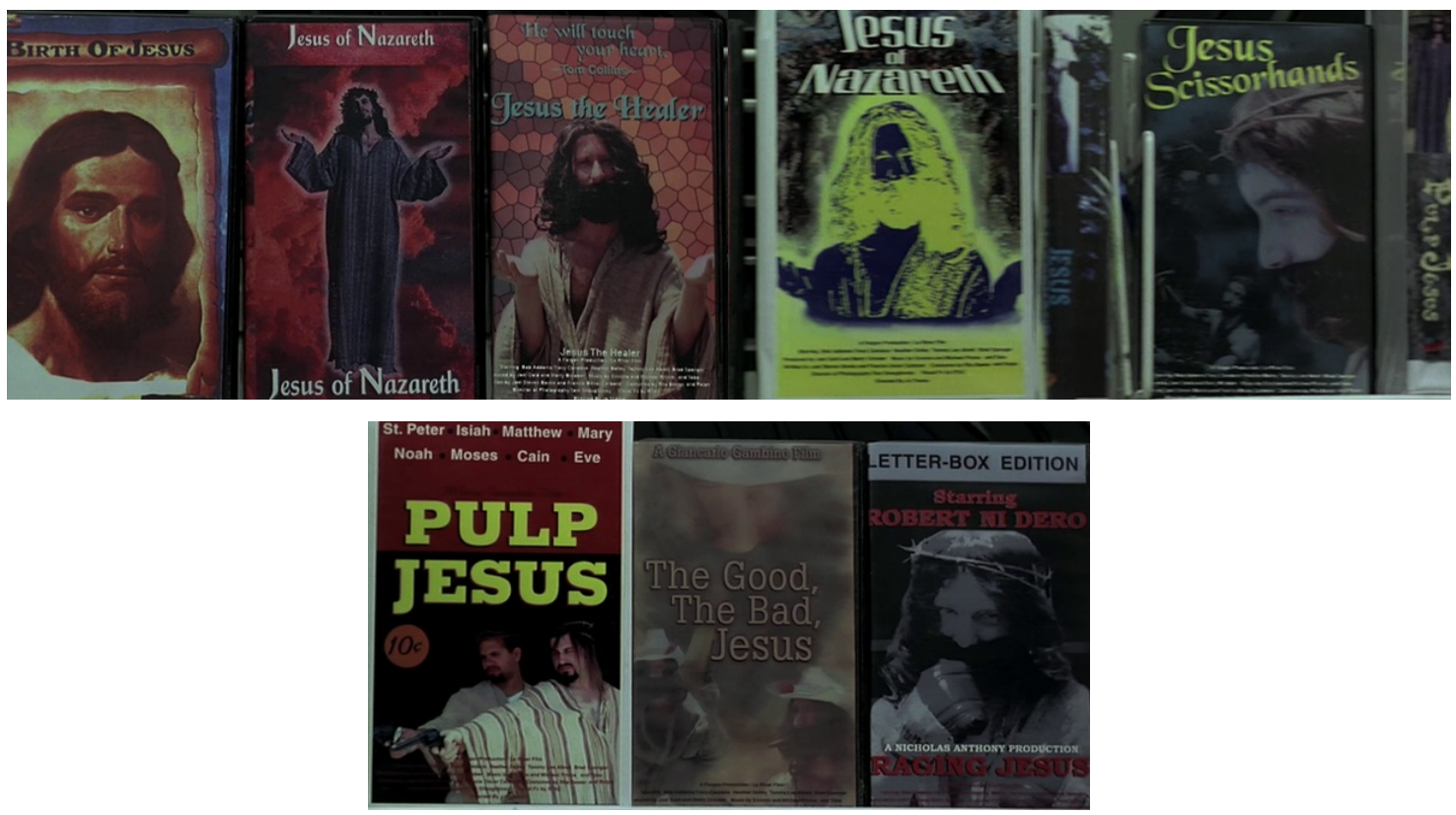

Figure 1: Eight Jesus video titles - mainstream \& mock

That video sequence was a delightful Hollywood insider joke, a witty nod to the cinematic appropriation of Jesus cleverly externalized for media consumption aimed at the religiously aware. It is also clear evidence of the Christ-figure's penetration into popular culture to the point where film directors deliberately make gentle fun of it.

\section{A Danger in Need of Pastoral Warning}

Although Christ-figure hunting can be seen as an adult version of a "Where's Waldo" / "Where's Wally" children-focused puzzle book, what may have started out as an academic adventure that is personally comforting, pedagogically astute, and thematically insightful, could quickly transform into a serious practical danger for neophyte viewers, and thus in need of a precautionary pastoral warning. For example, Linda A. Mercadante (2001, pp. 1-2) encountered potential negativity during her theological training of Methodist seminarians and lamented: "I worry that when they do find a film with distinct Christic allusions, they may uncritically accept images that have been used to promote or justify destructive human behaviour" [my emphasis].

She was referring to Lars von Trier's depressing drama, Breaking the Waves (1996), which won the Grand Prix du Jury prize at the 1996 Cannes Film Festival. It starred young Bess (Emily Watson), a simple-minded, God-fearing woman who displayed potential Christic properties, including private God talk, but she suffered under the strict Calvinism of the Free Presbyterian Church in northern Scotland. Whereas one could interpret Bess's God talk sequences as a manifest sign of mental aberration, Stephen Heath (1998, p. 95) claimed that: "Bess is in dialogue with God to whom she literally gives voice, her own voice dropping into a gruff maleness as God admonishes, questions and on occasion amiably chides her" [my emphasis], and in that process perpetuating the Classical western philosophy/myth of a masculine Christian deity. 
But more disturbingly, Bess-as-Christ-figure willingly acted as a prostitute and submitted herself to repeated sexual violence in the sincere belief that her sexcapades would help cure her much-loved, paralysed husband, Jan Nyman (Stellan Skarsgård). Prior to eventually being physically committed for her behavioural aberrations, she unflinchingly goes out to a derelict ship full of barbarous sailors, who violently gang rape her causing her death. Thereafter, her bedridden husband miraculously recovers, Bess's cloth-wrapped body is honourably buried at sea by her husband and crew, followed by a touch of magical realism when two large church bells hang supernaturally in the sky (see Figure 2) and ring very loudly which is heard clearly by the oil platform crew although undetected by their onboard radar despite the operator scanning "all the fucking ranges." This mystical event strongly implies that heaven had intruded into the mundane world to applaud Bess's selfless (sexual?) sacrifice.

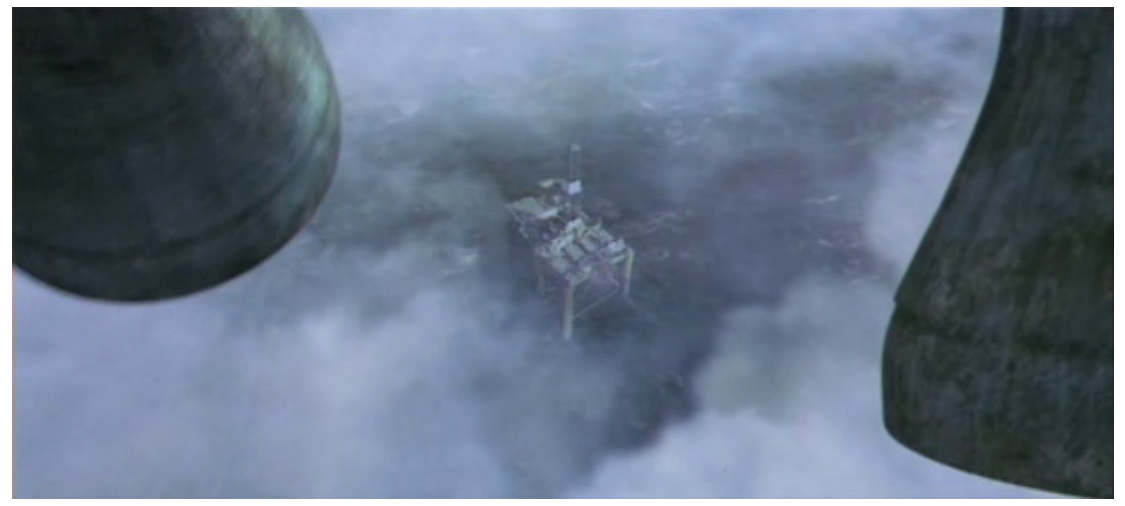

Figure 2: Supernaturally-suspended ringing church bells

One hopes that impressionable young women (and men) do not emulate Bess-theprostitute's self-engineered sexual victimization thinking it is God-sanctioned or acceptable Christic behaviour just because it was wrapped in a (delusional?) banner of love. iii Furthermore, one does not personally believe that God wants you to become a prostitute as a means of health improvement for a sick spouse. Indeed, one could argue it was Bess's death and willingness to put her husband first and not her rampant sexual activity that prompted the miracle of the bells. Nevertheless, Breaking the Waves (1996) was a subversive application of the Christ-figure that proved that even its ontological existence does not necessarily mean that it is a good thing or to be emulated on Earth by humanity. Lars von Trier's construction of Bess's "goodness" as masochistic debility had somewhat dubiously valorised male domination and invested sexual violence with redemptive meaning (Faber, 2003). In short, Mercandante was right to be concerned.

\section{Eleven Types of Academic Disquiet Concerning the Sacred Subtext Enterprise}

The critical film and religion literatures were selectively reviewed and integrated into this text to enhance narrative coherence (albeit, with a strong reportage flavour) utilizing textually-based humanist film criticism as the guiding analytical lens (Bywater \& Sobchack, 1989, pp. 24-47; Telotte, 2001, pp. 35-38). Although less foreboding than the potential danger identified above, but nonetheless annoying from a scholarly point of view, a preliminary scan of the popular cinema revealed at least eleven types of academic disquiet that one can potentially encounter during the hunt for cinematic Christ-figures. ${ }^{\text {iv }}$ All of which are worthy of exploration, namely: (1) When Factual Minimalism Equals Certainty: Holy Hope, (2) Misidentification: When Something Supposedly "Christian" Was Something Else, (3) When Nothing Equals Something: Creatio Ex 
5 One Danger and Eleven Types of Academic Disquiet Whilst Hunting for Cinematic Christ-figures

Nihilo, (4) Spiritually Negating Christian Iconography: Form Versus Substance, (5) Some Problems with the Secular-is-Sacred Argument, (6) Film is Not a Substitute for Faith, Religion, or God, (7) Rewriting the Film: Aesthetic Violence?, (8) Tenuous Links, Strained Associations, and Uncertain Correspondences, (9) Rejecting Overt Religion for Covert Religion: Distorting Theology and Misdirecting Faith?, (10) From Symbolism Fatigue to Symbolism Cynicism, and (11) Pattern Appeasement: From Being Uncritical to Narrative Insights.

These types do not cover the gamut of disquiet, or are necessarily mutually-exclusive categories because of minor overlaps and duplications that can occur when viewed from different perspectives. Indeed, each type of disquiet could be the subject of a separate article itself! Nevertheless, they are still worthy of brief academic consideration here; if only for consciousnessraising purposes given that the quest for sacred subtexts has already irked many religion scholars, film commentators, and lay people alike, as will be verified below.

\subsection{When Factual Minimalism Equals Certainty: Holy Hope}

In a particularly absurd example of seeing religious "faces in the clouds" (Telford, 200o, p. 35), movie fan Lance Good (1998b, online) suggested that Dr. Kathryn Railly (Madeleine Stowe) in Twelve Monkeys (1995) was a Mother Mary figure based, in part, upon the flimsy evidence that: "Kathryn and Railly have three letters in common, namely "ary" (in the order they appear in kAthRYn) - She is also an "M.D." which would provide the "M" to complete "Mary."' Equally unbelievable, he also argued that the unnamed "other Apocalyptic Scientist Nut is [the Apostle] Paul" because: "BEWARE!!! THIS IS NOT FUNNY - The blue underwear that the airport security guard holds up indicates that Paul has the notorious "blue balls" syndrome since he is unmarried and encourages celibacy, see 1 Corinthians 7" (Good, 1998a, online) [original emphasis]!"

When Good-the-fan failed to reach a decisive conclusion about the religious subtext in Twelve Monkeys (1995), he turned this lapse in scholarship into a bland religious asset by claiming: "This, I think, is the genius of the movie. Scholars try to construct what happened to Jesus but no two scholars totally agree" (Good, 1998b, online) [my emphasis]. Thereby, justifying his own interpretative failure while providing another "brilliant" parallel between the film and biblical scholarship. Taking this argument trajectory to its reductio ad absurdum extreme, anything that is confusing, puzzling, disjointed, or in any other way violates narrative seamlessness, or accepted cinematic conventions, or inherent logical rigour, can now be claimed to be a profound theological insight which requires deeper contemplation-cum-insight.

Although movies can have Christ-figures deliberately built in (e.g., The Day the Earth Stood Still [1951]), others may not have had any hidden religious messages intentionally crafted therein; whether by the writer, the director, or the actor. ${ }^{\text {vi }}$ Therefore, trying to find (supposedly) hidden religious subtexts in their filmic fare (as opposed to other fortuitous finds) could be a fruitless exercise leading to interpretative distortions of the seeing-what-you-want-to-see kind; the sacred subtext equivalent of the "rose-coloured glasses" biasing error (i.e., preconceived tinted perceptions). For example, within the critical film review of Cape Fear (1991) by T. G. Vaidyanathan (1996, p. 74), he tried to force religious interpretations of the ex-con Max Cady (Robert De Niro) by arguing: "He is a bloodless abstraction, an unrealized idea in the mind of the scriptwriter (Wesley Strick). He is probably devised as a messenger of God, an Angel of Death, or whatever to vent his pentecostal [sic] fury on the guilt-ridden, sinful Bowdens...He remains an impossible cross between Christ and anti-Christ." 
Nevertheless, his confusion is understandable given Caddy's prison cell Holy Bible and other books, religious cards, military portraits, Stalin photograph, a cross dangling "TRUTH" (with Bible image) and "JUSTICE" (with dagger image) tattooed upon his back, scriptural verses tattooed elsewhere during boredom-driven acts of desecrating flesh (Deut. 32:35; Ps. 91:2; Matt. 26:18; Rom. 12:19; 1 Thess. 4:6), his quoting of the 17th Century Lutheran-cum-Catholic priest, Angelus Silesius: "I am like God, and God like me. I am as large as God, He is as small as I. He cannot above me, nor I beneath Him be," plus post-prison criminal crimes alongside various other contra-indicators.

Allan Casebier (1976, p. 154) also demonstrated this style of confusion when he noted how the Kafkaesque protagonist, Josef K (Anthony Perkins), star of the nightmare-within-a-labyrinth thriller, The Trial (1962), "has been viewed as a Christ figure or an anti-Christ figure, as both and as neither." This is especially maddening when Joseph McBride (2006, p. 133) noted that: "K.'s neighbor Miss Bürstner (Jeanne Moreau) seems sympathetic at first but then in a delayed panic cries out: “Jesus! I hope it's not political!"ii Politics! Don't go dragging me into it!"” [original emphasis], thereby utilizing the Jesus style of kyriosities (Staley, 2016, p. 237) whilst simultaneously echoing Jesus's political circumstances (i.e., a religio-socio-political radical operating under a repressive rule who admitted to Pontius Pilate that: "My kingdom is not of this world"-John 18:36). But elsewhere in the very same text, McBride (2006, p. 132) argued that: "Anthony Perkins as Joseph K., made Kafka's Everyman seem both more defiant and more truly guilty" [my emphasis], whereas the biblical Jesus was no ordinary man, he did not defy Governor Pontius Pilate, and he was deemed innocent by Pilate himself (John 18:38). ${ }^{\text {vii }}$ Apparently, beauty is not the only thing in the eye of the beholder. Furthermore, one must also contend with misidentification issues.

\subsection{Misidentification: When Something Supposedly “Christian” Was Something Else}

The mere fact that a Hollywood film contains a potential religious reference does not necessarily mean that there is a religious connection, or if existing, that it is necessarily Christian per se. For example, many viewers detected profound Christic allusions in the dystopian cyberpunk blockbuster, The Matrix (1999); especially when its hacker-hero, Neo/Thomas Anderson (Keanu Reeves) was identified as "the One" destined to free a subjugated humanity from the illusory computer-generated world run by intelligent machines that used human beings as disposable biobatteries. During Neo's deliberately engineered discarding-cum-rebirth in the Matrix's sewers, he is portrayed in a cruciform pose (see Figure 3), thereafter this miracle-working techno-Messiah helped crew the rebel hovercraft, "NebuchadnezzaR" (Mark III No. 11, built 2069), operating out of the free-human City of Zion. Neo is eventually killed, but aided by the love of his female sidekick with the religiously resonating name of Trinity (Carrie-Anne Moss), but actually a Mary Magdalene analogue, he is miraculously resurrected with new-found powers to defeat the Matrix. Of course, many other biblical allusions exist (Bassham, 2003; Fontana, 2003; Ford, 2000; Milford, 2010; Worthing, 2004). 


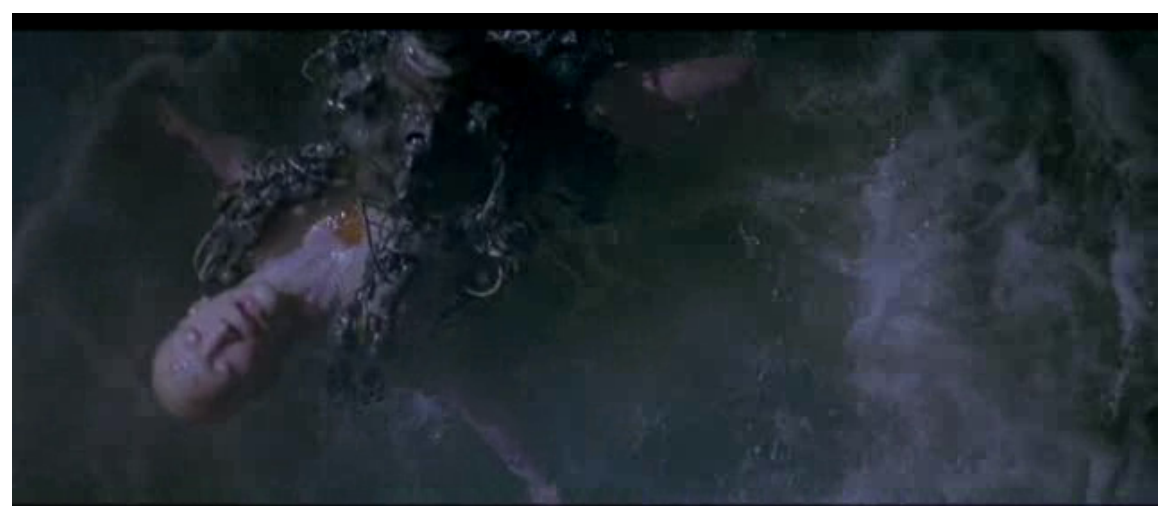

Figure 3: A discarded Neo (Keanu Reeves) in cruciform pose

The pairing of Neo-as-Christ-figure with Trinity-as-Mary Magdalene-figure makes subtextual biblical sense; however, in a valid counter-reading of Neo's female sidekick, P. Chad Barnett (2000) argued that:

...the Christian allusion to Trinity seems a red herring because it cannot possibly work in the context of the film. Given the Wachowski brothers' grab-bag of cultural references, Trinity might just as likely refer to the Trinity Site, code-name for the place in the Nevada desert where the first Atom-bomb was tested. The name Trinity could also be a reference to Lo chiamavano Trinita (They Call Me Trinity), a 1971 Italian Western, starring Terrence Hill. This reference stands to reason given its blend of "stand up for what is right" attitude with the traditional duster-a trope reworked in The Matrix (p. 367) [my emphasis].

However, one argues that the latent biblical subtext is more cogent than the action-packed Trinity being equivalent to a bomb site, or Terrence Hill's cowboy drifter, Trinita, lazily laying in a horse-drawn travois. Indeed, the biblical interpretation makes even more sense when the film franchise is viewed as a whole. As Frances Flannery-Dailey and Rachel L. Wagner (2004) confidently asserted:

...there are overt Christian references throughout the trilogy. From the prophesied birth of Neo, "the One," to his self-sacrificial death for humankind in [cruciform pose within The Matrix] Revolutions [2003], Neo is obviously crafted as a Christ figure [see Figure 4]. He functions as an exorcist who expels the possessing Agents from the bodies of those in the matrix (Mark 1.25); has foreknowledge of future events such as the death of Trinity (e.g., Mark 13, Matthew 24); travels in the hovercraft called the Logos (cf. John 1.1-18, the Greek logos normally translated as Word); has supernatural powers (e.g., Mark 4.35, 6.30, 6.45; cf. Mark 8.11); is resurrected (Mark 16, Matthew 28, Luke 24, John 20); and is transfigured into light, his face shining like the sun (Matthew 17.1-8, cf. Mark 9.2, Luke 9.28). (p. 99) [my emphasis].

Nor do the comparisons stop there because as they continue:

The response others have to him confirms their belief in this Christlike identity, since Link [Harold Perrineau], Niobe [Jada Pinkett Smith], and Morpheus [Laurence Fishburne] all seem to pray to him while looking up (Revolutions). Crowds throng around Neo, as they did around Christ [e.g., Luke 14.25; Mark 5.24; Matthew 4:25], asking for protection of loved ones and rendering him offerings (p. 99) [my emphasis]. 


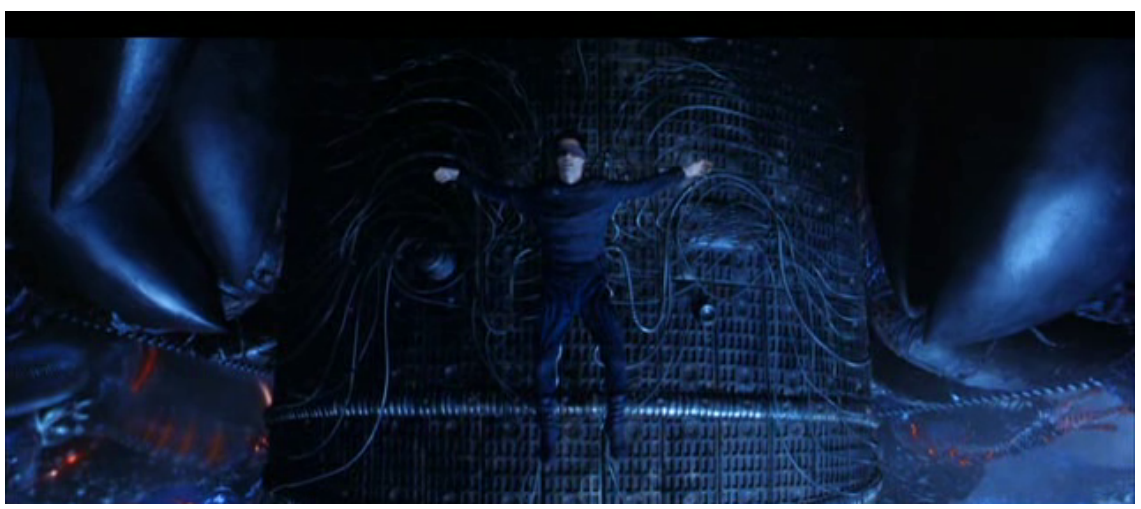

Figure 4: Neo's (Keanu Reeves's) self-sacrificial death in cruciform pose

Other critics similarly saw Christian parallels, but also Buddhist theological references within The Matrix (Ford, 2000; Ho, 2003), which at least suggests that sacred symbolism hunting is an ecumenical exercise. However, since a Christian reading of the film predominates today, as Jeffrey B. Ho (2003, p. 208) pedagogically warned: "Trying to transform a filmmaker's Jesus-like character into a Buddha in a typical U.S. college classroom can be quite challenging." Even within Christian readings of the film, especially by the first generation of people raised without religion in a post-Christian society, a different sort of Christianity is envisioned. As John Mabry (1999) noted:

...three popular films have been released which feature explicitly Gnostic themes, evidence that the myth is alive and active in the imaginations of Xers [Homo X-ian-born between 1960 and 1985]. The Truman Show [1998], Dark City [1998], and The Matrix [1999] all involve protagonists trying to escape from an artificial reality in which they are imprisoned. In each film it is knowledge which unlocks the key to their prison, and allows each to foil the power of the archons (p. 43) [my emphasis]. ${ }^{\text {ix }}$

If one takes the logic of such tentative parallels to its reductio ad absurdum level, then any film which has any biblical elements (e.g., scheming women, destruction, murder, spies, suffering, forgiveness) is automatically a de facto religious film. The real question reduces to how well it was done and/or how long could one sustain the parallels before it breaks down (into what exactly?). Father Peter Malone (1997, p. 70) proffered essentially the same argument when he said: "not every Mexican who is named Jesus is immediately a Christ-figure, or every Mafioso who desperately signs himself before being massacred." Father Joseph Marty (1997) concurred when he similarly said:

A woman with a child in her arms is not necessarily a nativity scene...a mother who holds the body of her son is not inevitably a Pieta... Discernment is necessary in order not to "baptize" hurriedly every allusion or every symbol, all the more so because it is today that they flourish, and publicity makes reference to them for purposes other than evangelizing! (p. 140).

As difficult as it is to assess whether a character is a religious figure or not, paradoxically, some authors have argued that the non-presence of a character is direct evidence of its existence! 


\subsection{When Nothing Equals Something: Creatio Ex Nihilo}

A seeing-what-you-don't-see phenomenon was argued by Donna Bowman (2001) concerning the modern-day Brazilian-French drama Central Station (1998; aka Centro do Brasil). She contended that the physical absence of a character named Jesus, his claimed Christ-figure status, and supposedly the father of Josué (Vinícius de Oliveira), was partial proof of Christ's existence in a compelling religious allegory of the "Christian mythos" (Bowman, 2001, p. 1). She even chided critics for not realising this (supposed) religious fact by arguing:

Here the Christ figure is not the hero - in fact, he is not even seen on screen. He is merely $a$ potential presence, spoken of with great confidence, but never met in person. This striking absence is so unusual for a Christ figure in film that, despite the copious internal clues that the film is a spiritual allegory, few critics caught on (Bowman, 2001, pp. 1-2) [my emphasis].

Furthermore, Bowman posited this unseen Christ-figure's existence by arguing:

...the invisible Christ of Central Station [1998] does not signal his identity with a sacrificial act. His chief defining characteristic is his absence; all the other traits attached to him - his drunkenness, his carpentry, even his surname - recede to the status of rumors when confronted with the one indisputable fact we know about Jesus: he is not here. Given his absence, the other characters in the film are free to decide for themselves how they will view him (Bowman, 2001, pp. 8-9) [my emphasis].

Therefore, while the film's on-screen characters are given free range to (subjectively) see what they want to see, the film audience (objectively) sees nothing of Jesus (whether as man or Christ-figure). The audience is now forced to hunt for the proverbial "faces in the clouds" (Telford, 2000, p. 35) via the other on-screen characters subjective impressions, with not even a word, Scripture-quote, cruciform posture, flash-back scene, or death-and-resurrection event to ponder!

In essence, Bowman (2001) had adopted a "When Nothing Equals Something" tactic to justify her interpretative stance. She then contended that the film's religious interpretation was difficult to see because of its distance from the Gospel narratives from which Christ-figures legitimately spring. As she put it:

Perhaps part of the reason Central Station [1998] is not immediately seen as a film about Christian faith is that the family relationships are not fixed and directly referable to the Gospels. Jesus as the father and Josué (Joseph) as the son certainly represents an inversion of the hierarchy we expect...The temporal inversion, in which forerunners become sons and sons become fathers, gives the film at least initial resistance to a straightforward allegorical reading, and possibly contributes to most viewers' overlooking the Christian symbolism throughout (p. 7) [my emphasis].

However, audiences may have simply overlooked such Christian symbolism because they were not there to begin with, or at the very least, it was done so poorly that any intended scriptural correlations suffered to the point of non-recognition.

The reductio ad absurdum logic of Bowman's position is troubling because a negation cannot prove existence. If it were otherwise, then no evidence is automatic proof of whatever one wishes to posit, Christ-figure or not! How many missing Gospel facts, significant absences, confusions, odd inversions, and non-existing parallels does it take before the supposed Christian allegory degrades into scriptural nonsense (even if still a good story)? Bowman (2001, p. 9) argued that as the crusty sexagenarian Isadora/Dora (Fernanda Montenegro), a retired school-teacher, 
and her de facto son "Josué follow the void that Jesus has left, she is convinced by the absence as she could not have been [convinced] by the presence," thereby inviting "a theological reading as the story of human beings struggling to maintain a relationship to an absent God" (Bowman, 2001, Abstract). Unfortunately for Bowman, others have higher standards of proof.

It appears that Bowman's dogmatic desires may have gotten in the way of cinematic Christfigure analysis; even though there are many good Christian parallels (Rebolledo, 2005). More worryingly, is such a response symptomatic of a more pressing $21^{\text {st }}$ century theological need, namely, to account for Christ's failed Second Coming post-Millennium? If one were to translate the logic of Bowman's argument into contemporary theology, then Jesus's failed arrival is sure-fire proof that he exists and is definitely coming. Presumably, one just has to have scholarly faith, look for (and find) very subtle hints (because the obvious ones are hard to find), and hang on a bit longer to be ultimately vindicated.

Conversely, possessing solid Christian iconography within a conventional feature film can still be potentially problematic and fraught with interpretative dangers.

\subsection{Spiritually Negating Christian Iconography: Form Versus Substance}

Legitimate Christian iconography does not necessarily make a secular film religious or even spiritual. Donald Lyons (1992, p. 6) argued that the neo-noir thriller Bad Lieutenant (1992) starring corrupt cop, Lt (Harvey Keitel) had the abstract feel of a Passion Play, and also contained scenes parodying epiphany (Hasenberg, 1998), but he was unsatisfied and concluded:

...[director Abel] Ferrara's art has finally, I think, no real religious dimension. There is masterful iconography but no actual spirituality. There is no redemption for the [vicepursuing, unnamed New York homicide] Lieutenant, whose freeing of the rapist seems exhaustion more than grace or even imitation of the nun's (itself overwritten and phonysounding) act of grace. A ravaged nervous system is simply yielding to a stray impulse. There is no Purgatorio in Ferrara, only an infernal toilet. Harvey Keitel crying out in church echoes for a second Victor McLaglen [playing Gypo Nolan] in The Informer [1935], but even [John] Ford's sentimental religiosity is alien to Ferrara. He seems a frenziedly brooding diagnostician of pleasure - a kind of puritanical Russ Meyer (Lyons, 1992, p. 8) [my emphasis].

Although George Delalis (1993, p. 45) noted that: "Ferrara's compelling use of religious imagery adds to the power of the film," unchecked, it led him to make a strained link between Christ and the repugnantly self-absorbed "Lieutenant [who] is too far gone by the time that he seeks redemption. In his drug-ravaged mind, he sees himself as Christ. He will die for the sins of others. A crack house becomes the scene of his Last Supper" (Delalis, 1993, p. 46). Simon J. Taylor (2003) similarly searched for a theology of salvation involving Lt and Christ, but concluded the quest was flawed in nature, scope, and was ultimately fatalistic because its salvation attempt avoided struggle, did not change, or even attempt to redeem the wider world, and it focused upon death not life; but nonetheless, he valued Ferrara's film precisely for its flaws.

In a philosophical mood, Father Richard Blake (1995) even questioned the very soundness of religious figure hunting. He asked:

...how can believing critics be sure they are not bringing their own subjective set of beliefs into their reading of the film, and how can theologians not take out of a film the predetermined meanings that they want to find? Can some methodology be devised to 
permit a faith dimension to be found in film, as it is in the other arts, while preserving the integrity of the text? Because of their subjective character, these questions may never be resolved with complete clarity, but devising some canons of critical methodology must precede any discussion of individual films or their religious content (p. 4).

Such is the case regarding the cinematic Christ-figure, but which can be dealt with by devising a taxonomy of construction features. Another potential obstacle encountered in the religious film quest is to claim that the sacred is secular, which itself is problematic, but easily addressed.

\subsection{Some Problems with the Secular-is-Sacred Argument}

It could be argued that the secular world is sacred, that is, everything is holy, and so the division between the "religious" and the "non-religious" makes no sense because it is an artificial bifurcation, a conceptual construct-cum-contrivance that has no ontological basis in reality. This basic position was televisually illustrated by a Federation colonist on Dovan V, Lakanta (Tom Jackson), a $24^{\text {th }}$ Century Puebloan descendant of native North American Indians. He explained to Enterprise-D acting ensign, Wesley Crusher (Wil Wheaton), in the "Journey's End" episode of Star Trek: The Next Generation: "Everything is sacred to us. The buildings ... the food ... the sky ... the dirt beneath your feet ... and you. Whether you believe in your spirit or not ... we believe in it. You are a sacred person here, Wesley" (quoted in Sherwin, 1999, p. 85).

Religion-and-film scholar John R. May (1997, p. 34) similarly claimed: "There are...solid and convincing grounds for asserting that any film, even those without explicit religious elements, can still be considered as potentially religious, if not Jewish or Christian or Catholic" [my emphasis]. Whilst his scholarly peer Peter Fraser (1998, p. 53) argued that: "one can find inherently religious material even in films by directors who openly deny the faith, such as Luis Bunuel [1900-1983], because what is harder to deny than dogma is a cultural epistemology" [my emphasis].

Logically speaking, if the secular is sacred, then how can one make a non-religious, nonfaith film? Furthermore, such a theological position does not advance the cause of cinematic theology or aid any typological categorisation efforts. Why? Because it could mean that all films are religious films, all dialogues are sacred stories, all visual texts are religious texts-cum-icons, and so all life portrayed are religious lives, thus stymieing further investigation beyond the putatively obvious. However, much of Western culture is informed or shaped or touched by religion simply because it reaches into all aspects of everyday life which would be churlish to deny.

\subsection{Film is Not a Substitute for Faith, Religion, or God}

Regardless of how well religious elements can permeate cinematic texts, film is not the audiovisual equivalent of faith, religion, or God (whether in the form of celluloid, magnetic tape, or metal-and-polycarbonate plastic) because: "Film simply will not deliver a systematic theology" (Marsh \& Ortiz, 1997, p. 248), nor evolve into a legitimate religion, notwithstanding the nascent First Church of Simba (Stoffel, 1998, sec. 4A, para. 5) based on Walt Disney's animated adventure The Lion King (1994). Why? Because "the cinema "word" is, in the most absolute way, not divinelyinspired or guaranteed, no matter how approved a film might be by church authorities" (Baugh, 1997, p. 4). Even with pronounced film-Scripture parallels, will it have the same effect as the original holy text? This was essentially the criticism of Father Michael Paul Gallagher (1997, p. 152) 
regarding E.T., the Extra-Terrestrial (1982) when he asked: "is the finale...a genuine moment of vision and self-transcendence, liberating of the spiritual imagination, and even Christian in its echoes, or is it merely a soft manipulation of seemingly spiritual emotions, short-lived and lacking in depth?” Thus prompting his call for a biblically inspired (1 Cor. 12:10; John 16:8; 1 John 4:1; Rom. 12:2), but cinematically-focused act of spiritual discernment because "a film may induce a certain satisfaction, even a felt enlargement of heart, but this yardstick of feeling is not in itself a valid criterion of authenticity" (Gallagher, 1997, p. 153).

Furthermore, film-as-flickering-shadows are not meant to replace Scripture, but rather, function as road maps pointing towards divinity whilst pursuing "overtly religious themes in a secular "wrapper"' (Ellis, 2001, p. 304), and thus entice us into theological thought by forcing us to focus upon what "religion" may mean to us. However, one way the cinematic word comes close to being religiously inspiring is as film philosophy. As Sylvain de Bleeckere (1997) pointed out regarding the Book of Revelation within the Christian canon (alternatively called the Book of Apocalypse):

The theologian [Edward] Schillebeeckx [1914-2009] rightly describes the biblical apocalyptic texts as a religious philosophy of life. Film can also develop into such a philosophy of life in a technological society...in the postmodern culture, film can both discover and explore its affinity with the religious apocalyptic vision inasmuch as film, with its visual composition and sense of movement, stands firmly anchored in time (p. 102) [my emphasis].

Conversely, Father Richard Blake (1995) highlighted the possibility of devaluing the faith when analysing the screen without a balanced perspective because:

For a Christian theologian, the Incarnation of Jesus as Man marks the beginning of a unique messianic event, one whose uniqueness can be lost or trivialized by overly facile comparisons to the icons of popular culture. The notion of a loving God rests at the core of the JudaeoChristian tradition, but it is a love of such power that only at the risk of cheapening it can it be readily mirrored in every love story that involves some element of self-sacrifice. Many romantic stories in film can be called examples of "redemptive" love, but that is quite different from saying the story is a parable of the Redemption, which for a Christian is a privileged instance of love on a scale that defies the imagination (pp. 3-4) [my emphasis].

Therefore, care must be taken to stop the cinematic theology-of-ordinariness (as a reaction to theological elitism) from descending into petty exercises in the cinematic theology-of-thetrivial; especially when what is truly wanted by the religious community was colourfully described as "deep-pan, and not just thin-crust, theology" (Marsh \& Ortiz, 1997, p. 255).

\subsection{Rewriting the Film: Aesthetic Violence?}

For religion-and-film scholars Joel Martin and Conrad E. Ostwalt Jr. (1995) the Christian symbolism quest was:

...sometimes taken to ridiculous extremes when critics, focusing on the didactic function of film, look for "Christ figures" around every corner in order to impart Christian teaching. "Rewriting" virtually every film in terms of the Christ story or as a battle between good and evil, they dilute and undermine the power of this interpretative standard (p. 15) [my emphasis]. 
When potentially tenuous links approach the realms of the ridiculous, it begs the question of whether religious insights are truly there waiting to be discovered, or if they are being superimposed upon the secular storylines by eager viewers. And especially concerning animal Christ-figures wherein one has departed from the human realm to a lesser biological kingdom to find a hidden superior being, for example, Babe (voice of Christine Cavanaugh), the holy hog star (see Figure 5) of the delightful farmland fable, Babe (1995) and its sequel Babe, Pig in the City (1998). ${ }^{\mathrm{x}}$

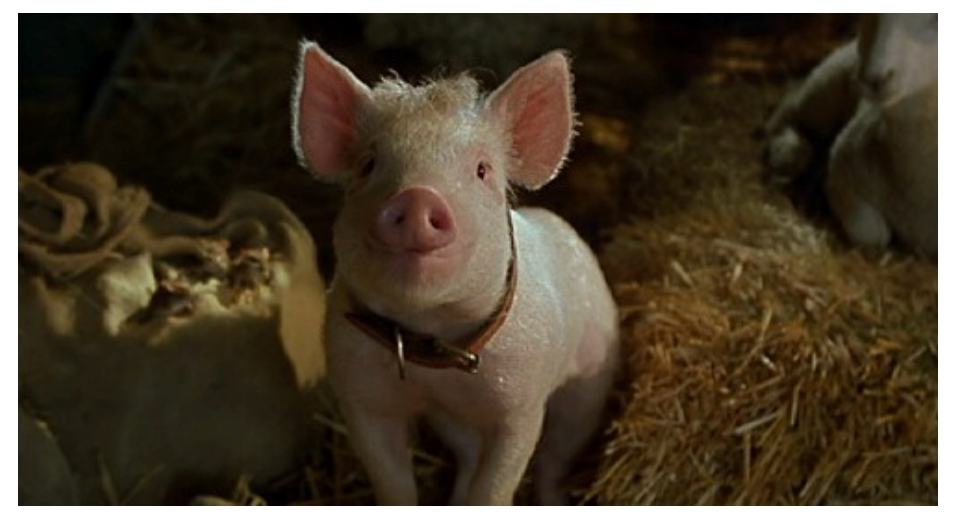

Figure 5: Babe, the porcine Christ-figure (voice of Christine Cavanaugh)

Consequently, the rewriting of overtly secular films as Christian sacred subtexts was seen as a form of aesthetic violence. For example, Damien Chase (1996, pp. 327-328) criticised Avent Childress Beck's attempt to trace Christian allegory in the Vietnam war movie Platoon (1986) because he failed "to take any account of generic convention, and little notice of social and political comment in the Vietnam film, effectively "rewriting" the film to serve a new purpose" that eschewed the radical changes in American attitudes that underpinned its liberal anti-war sentiment. Likewise, Father Richard Blake (1995) warned that:

If pursued with vigor, it can tempt the eager critic to work violence upon the text of the film by imposing religious meanings on perfectly secular films and unearthing religious symbols which are neither intended by the film makers nor congruent with the narrative and thematic intent of the film. In its most extreme forms, it reduces film to a catechetical or homiletic exemplum, which is fine for discussion groups but questionable for criticism (p. 3) [my emphasis].

Furthermore, Father Blake (1995) argued:

It is, for example, possible for a religiously inclined critic to argue plausibly that Superman (Richard Donner, 1978) retells the story of the Messiah. The hero [Kal-El/Clark Kent/Superman (Christopher Reeve)] is, after all, sent from another world by a benevolent father [Jor-El (Marlon Brando)], succumbs for a while to the powers of darkness, then through his heroic agon rises from apparent death and restores love to earth, as imagined in his union with the life symbol, Lois Lane [Margot Kidder]. This comparison is interesting but it reveals little about the film. Similar messianic interpretations could be imposed on any number of genre, especially Westerns (p. 3).

Although agreeing that Westerns can harbour Christ-figures, notably Shane (Alan Ladd) in Shane (1953) and the Preacher (Clint Eastwood) in Pale Rider (1985), and agreeing that they exist in other film genres, one strongly disagrees with Blake's criticism of Superman (1978). Why? Because his brief analysis of its subtextual storytelling was very good indeed without unlocking 
the even greater Christic parallels built therein and in its sequels (Christoforidis, 2014; Dean, 2016; Kozloff, 1981; Kozlovic, 2002a; Revington, 2018), let alone acknowledging the other New Testament analogues that buttress Superman as a Christ-figure (Kozlovic, 2002b, 2003).

Interestingly, rewriting films can produce unusual counter-readings. For example, Roland Boer (1995) read The Terminator (1984), starring Sarah Connor (Linda Hamilton), mother of the yet-to-be-born Messiah John Connor (J. C.), as an anti-abortion text rather than a Christ-figure film. As he argued:

Since the Virgin Birth motif raises Sarah's conception and fertility to the sublime Good, [Kyle] Reese's [Michael Biehn's] protection of her from an inhuman agent who would destroy her in arresting her pregnancy translates into the supreme anti-abortionist position. With some ideological legerdemain, the narrative associates totalitarian repressiveness not with the pro-life faction but with the Terminator [Arnold Schwarzenegger], whose persona...is Fascist. The fact that he is reminiscent specifically of Nazi exterminators, through Reese's allusion to death-camps and the number on Reese's arm, equates abortion with unspeakable atrocity (p. 48) [my emphasis].

Indeed, cynically manipulating the Jesus persona occurred in the foreign comedy Looking for Jesus (1982; aka Cercasi Gesu) wherein a Jesus-looking hitchhiker Giovanni (Beppe Grillo) was headhunted by a Vatican entrepreneur, turned into a tele-visible Messiah (see Figure 6), and became the publicly acceptable face for a forthcoming election (regardless of his personal background, history, or religious attitude). As Peter Malone (1997, p. 57) opined: "This is evangelization by media, a publication of the Gospels with live photography of Jesus - Jesus in action.”

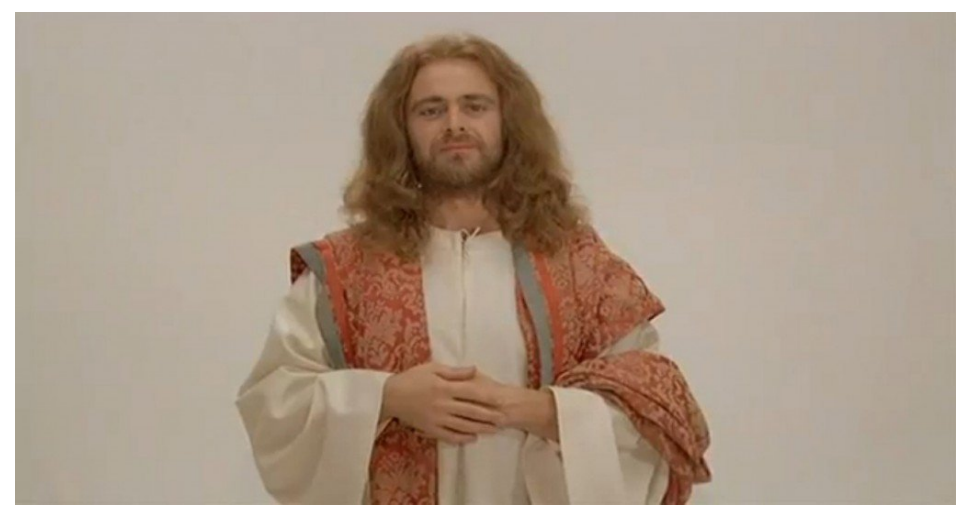

Figure 6: A Jesus-looking Giovanni (Beppe Grillo)

Sometimes, aesthetic violence is inflicted upon Christ-figure patterning for commercial reasons. For example, Mad Max (Mel Gibson) in Mad Max Beyond Thunderdome (1985) was deliberately designed as "Jesus in black leather" (Lofficier \& Lofficier, 1985, p. 15) by co-producer and co-screenwriter, Terry Hayes. As he thoughtfully mused:

I'm uncertain it's whether or not you believe in religion, God, or any of those things, but, to a larger extent, that's the currency of the story of, say, Jesus, an ordinary guy, a carpenter, who maybe isn't the son of God, but lays down his life for something (Lofficier \& Lofficier, 1985, p. 16).

Although recognizing death as a structural feature of the redeemer Christ-figure, Hayes deliberately avoided doing so in practice. As Randy Lofficier and Jean-Marc Lofficier (1985) reported: 
Despite early rumors, the character [Max] does not die, although Hayes confesses that at one time, there was some truth to those reports. "It was originally intended to kill Max," the producer/writer admits, "but you get halfway through writing the story and you're not its master anymore, you're its servant. We just couldn't kill him. I honestly didn't know how to do it to get the story to work. So, Max survives" (p. 167) [original emphasis].

Max's survival results in a saviour that does not die thereby severely weakening the potency of the Christic subtext (akin to Jesus not dying at his crucifixion). Nor is Hayes's excuse convincing because Max could have rescued the children, died a martyr's death, and ended up in a cruciform pose; just like Colonel Robert Neville (Charlton Heston) in The Omega Man (1971). A Christ-the-redeemer death was the correct subtextual trajectory, but was presumably eschewed to pursue potential profits via sequels and not because of Hayes's creative drought. The dystopian franchise was belatedly resurrected with Mad Max: Fury Road (2015), but it pursued an ecological (not a Christic) theme. Of course, many other tenuous links, strained associations, and uncertain correspondences abound in this field.

\subsection{Tenuous Links, Strained Associations, and Uncertain Correspondences}

Arthur Becker (1994, p. 117) reviewed Robert Jewett's Saint Paul at the Movies: The Apostle's Dialogue with American Culture, and backhandedly claimed: "Happily, the author does not find a "Christ figure" lurking behind every klieg light." However, sometimes such criticisms appear justified. For example, Peter Fraser (1998) strained the boundaries of credulity concerning the pre-Code war film, A Farewell to Arms (1932), when he interpreted the wilful desertion of the American architect-cum-WWI ambulance driver, Lieutenant Frederic Henry (Gary Cooper), as going on a "Christian pilgrimage. He has renounced not the war, but the world, and for a love that has been marked as divinely favoured" (p. 96). "Frederick has become Christ-like in his pilgrimage away from the war through the valley of death to the bedside of his bride" (p. 94), the lovely English Red Cross nurse, Catherine Barkley (Helen Hayes). However, whether soldiers deserting an active front for self-centred romantic reasons equals Christic holiness is extremely problematic; especially since Jesus, although temporarily wavering, never abandoned his deadly mission, even when scared and his sweat was the size of blood drops (Luke 22:42-44).

Such tenuous links, strained interpretations, and uncertain correspondences can generate their own forms of aesthetic violence, especially from lovers of genre films who do not want them co-opted by religionists. For example, biblical scholar David Jasper (1997) was a tad apologetic about this trend when he argued:

Generally speaking, there is a nervousness about such references [to Christ-figures], indicated by a repeated disclaimer that there is, of course, no overt theology in Edward Scissorhands [1990] or Shirley Valentine [1989]. Viewers not inclined to impose such readings on these films might be justifiably skeptical or even affronted by the suggestion that religion is being inflicted upon them indirectly (p. 237).

One can even detect a symbolism backlash in the fantasy film, Jonathan Livingston Seagull (1973), based upon Richard Bach's book of the same name, when the winged protagonist (voice of James Franciscus) said: “Don't let them...make me a God....I'm a seagull” (Pomeroy, 1974, p. 49)! Translated, updated, and reapplied for today's audiences, the cry might now be: 'It's only a film Virginia, not God!' Furthermore, David Jasper (1997) was also reluctant to accept religious references in films just because there were tentative biblical parallels. As he admitted: 
...I would hesitate a little before I give assent to the claim that the issues raised by the Terminator movies are the issues explored by Isaiah, Jeremiah and Ezekiel. From the writings of the Hebrew prophets arises an enduring tradition of theological reflection which is intrinsic to the texts themselves. These are books which burn with fire of religious passion and the issues explored in them cannot be disentangled from that passion. The same cannot be said of James Cameron's movies... (p. 238).

Father Lloyd Baugh (1997, p. 249) was of a similar mind regarding Jesus Christ, Superstar (1973): "The only reference to a kingdom is when Jesus [Ted Neeley] says rather lamely to Pilate [Barry Dennen]: "There may be a kingdom for me somewhere." It hardly qualifies as a theological reference." A similar complaint could be levelled at John Baxter when he claimed that Mad Max (Mel Gibson) was a Christ-figure in Mad Max (1972) and Mad Max 2 (1981; aka The Road Warrior) simply because he is "taking on the sins of the whole world of which he is a part" (Baxter, 1985, p. 117). Whilst George Aichele (2002, p. 7) argued that Conan (Arnold Schwarzenegger) in Conan the Barbarian (1982) "strikes cruciform body-building poses composed of equal parts venerable European traditions of religious art and the popular 'pulp' magazine fantasy art of Frank Frazetta," but then claimed: "Nevertheless, Conan is no Christ, and not even a Christ-figure" despite his iconic Christic pose (see Figure 7). And so determining what legitimately constitutes a Christfigure can be problematic, but certainly worthy of future scholarly effort.

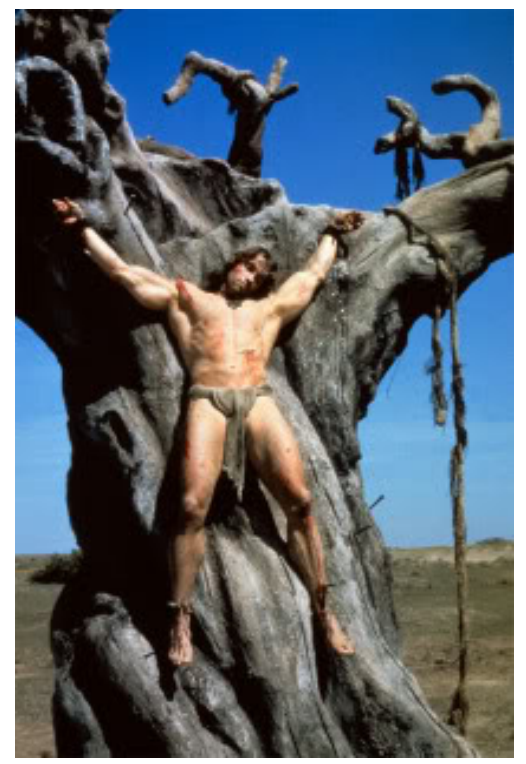

Figure 7: The crucified Conan (Arnold Schwarzenegger)

Nor does this sort of criticism stop at just Christ-figures, it also applies to other subtextual biblical characterisations. For example, Father Peter Malone (1990) thought it was unwarranted to tag some characters as antichrists within Jesus of Montreal (1989) because:

It dignifies several of the characters, whose lives are shallow but whose up-front manner is pretentious, to call them antichrist-figures. They are too trivial as human beings: the fawning socialites, the melodramatic media hostess and her tears, the auditioning agent, the brutal producer (pp. 41-42).

Strained, competing, and conflicting identification of Christ-figures can also be annoying, if not outright frustrating at times. For example, Episcopal priest, Robert Farrar Capon (with his wife Valerie) viewed American Beauty (1999) and identified four candidates for the film's 
putative Christ-figure. Namely: (a) the Colonel's son, Ricky Fitts (Wes Bentley), (b) Lester Burnham (Kevin Spacey), (c) Colonel Fitts (Chris Copper), and (d) the Colonel's wife, Barbara Fitts (Allison Janney), all of which were interesting, but potentially incredulous Christ-figures based upon flimsy evidence. For example, the Colonel's son Ricky was chosen because:

...he even acts like Jesus. When his father physically abuses him, he never strikes back. And then there's his video camera. He lovingly preserves everything he sees with it: a paper bag dancing in the breeze with some leaves, children playing, a dead bird, mourners at a funeral. The camera, in fact, becomes an image of his having the whole world in his hands. And at the end, when he's about to leave for New York, he says to his mother, 'Take care of Dad,' which is a neat twist on Jesus' last word to his own mother, 'Women, behold your son' [John 19:26] (Capon, 2003, p. 20)

But one would argue that there is a world of difference between taking care of someone and just observing them.

Secondly, Lester Burnham was chosen as the putative Christ-figure because:

...after he overhears his daughter's girlfriend say she likes men who are in great physical shape, he goes onto a middle-age frenzy of push-ups and weight training. But then, in the scene where the girl confesses she's still a virgin, his fantasy life instantly dematerializes, and without laying a hand on her, he gently smiles at her. As far as I'm concerned, that's an image of his restoration to the truth of his being. In that moment, the way forward to his becoming a caring father and loving husband opens up for him. For the first time in the movie, he's truly alive. And to drive that point home, the director had the brilliant idea of bringing that smile back in the shot of Burnham's face after he's dead [see Figure 8]. For me, it's the smile, not the words he says in the voice-over, that becomes the crowning image of the picture (Capon, 2003, pp. 20-21).

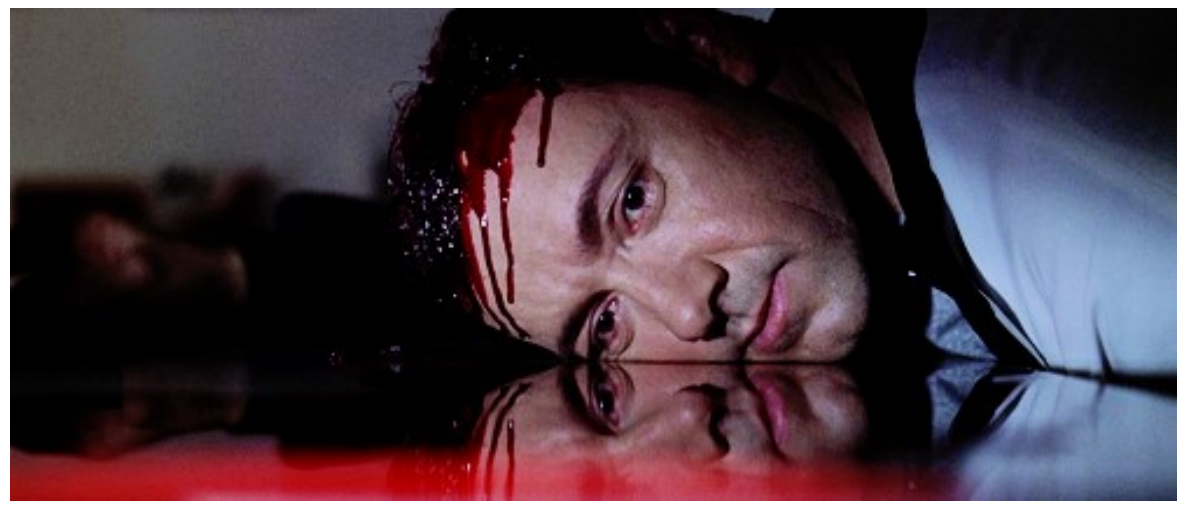

Figure 8: The smiling but dead Lester Burnham (Kevin Spacey)

But does all this filmic flimsiness make Burnham a Christ-figure, rather than just a sexually frustrated, but now happy stiff? Especially considering the biblical Jesus's death was an agonising, definitely smile-less affair (Isa. 53:3-4; Matt. 27:32-50; 1 Peter 2:21, 4:1) as gruesomely depicted in The Passion of the Christ (2004). Indeed, some critics considered this famous feature film to be Christian torture porn (Lacy, 2014) and because it contained "pervasive occurrences of sadism, epitomized by Mel Gibson ...which transforms venerable suffering into a litany of torturous assaults" (Allen, 2013, p. 172).

Thirdly, Colonel Fitts was chosen as the putative Christ-figure because: 
...the movie doesn't show him literally dying or rising. But he does destroy his previous life of denial when he makes his homosexual advance on [Lester] Burnham, and he ends his present life for all practical purposes when he kills Burnham. And when his wife silently promises to take care of him, there's at least a hint of resurrection. I do realize I'm making somebody who virtually commits suicide into a Christ-figure. But that's okay. For all practical purposes, Jesus himself was a suicide. He said, 'No one takes my life from me; I lay it down of myself [John 10:18].' He set himself up to be crucified. If he'd stayed out of Jerusalem, at least he wouldn't have died at that particular Passover (Capon, 2003, p. 21) [my emphasis].

But even if Jesus did lay his life down himself, did not God purposely send Jesus to Earth to provide the ransom sacrifice (John 3:16) and thus Jesus was under holy orders so to speak, therefore God is the real "killer" here. And especially considering that after Jesus's earthly arrival, God did nothing to save his son from imprisonment, torturous treatment, or grizzly execution simply because the purpose of Jesus's life was his death. Albeit, Jesus's post-crucifixion resurrection and ascension into heaven to sit "on the right hand of God" (Mark 16:19) mitigates the "killer" tag, the ontological standing of death, and the moral status of the sacrifice directive.

Fourthly and finally, the Colonel's wife, Barbara was chosen as the Christ-figure because:

...she's dead for the whole film, and she has no apparent resurrection. But if you're going to talk about life in the midst of death, why can't I take her ongoing death as at least an image of new life? Sure, most people would say it was just her way of coping. But so what? Corpses don't cope; only people who are alive do. And anyway, she's the only one who understands everything that's going on...She understands the way that God understands. Like God, she just puts up with everything. She takes the messy lives of those around her into her death and lets them be, just as God takes all the sins of the world into his death on the cross and lets them be" (Capon, 2003, p. 21).

\section{Furthermore:}

Her son seems to have faith in her forgiveness when he commits his father to her care. But about her husband, we just don't know: the movie gives us no image of faith on his part. That doesn't matter, though. Whether he comes to faith or not, she still understands and forgives. All of which is made clear by her final scene in the movie. She's sitting at the foot of the staircase, head bowed and ears covered by her hands. And when the gunshot goes off, she doesn't even move a muscle! If that image doesn't point to 'Father, forgive them, for they know what they do [Luke 23:34],' I don't know what does (Capon, 2003, p. 21).

But how does lack of responsiveness necessarily equate with divine forgiveness? Nevertheless, the above-mentioned competing readings appear to be excellent examples of seeing what you want to see that may push (in)credulity to new limits in pursuit of finding Christic subtexts in one's filmic fare.

Interestingly, J. David Bridge (1994, p. 112) made similar testy remarks about Reverend Larry Kreitzer's analysis of the quasi-biblical epic, Ben-Hur: A Tale of the Christ (1959) when he claimed that Kreitzer "finds significance in superficial similarities in a way that makes one suspect he would find a connection between Mary's gift of perfume [John 12:3] and an advertisement for Chanel." Thus proving that interpretative difficulties are not limited to subtextual Jesus-hunting. But what about rejecting overt religion for covert religion, distorting theology and misdirecting faith? 


\subsection{Rejecting Overt Religion for Covert Religion: Distorting Theology and Misdirecting Faith?}

Ironically, the search for holy subtexts in contemporary feature films has resulted in some critics actually rejecting overt biblical films in favour of non-biblical films that illustrate humanity in a (supposedly) more religious way. For example, Malcom Boyd (1962) complained that:

A number of theologians began to say that a religious movie, The Ten Commandments [1956], was not religious at all, and that an extremely evil movie, Baby Doll [1956], possessed real religious significance. These theologians began talking about a "doctrine of man" in the movies, claiming they found such a doctrine implicitly revealed in movies where it was not explicitly intended. Moreover, the theologians began to discern symbols of God in some of the movies which, they said, "state accurately man's existential situation." They must have merely enjoyed seeing dirty pictures, for they flocked to all the wrong movies and became more and more insulting about biblical pictures like Solomon and Sheba [1959], The Ten Commandments [1956], David and Bathsheba [1951], and Samson and Delilah [1949] (p. 153).

Similarly, religion-and-film scholars Clive Marsh and Gaye Ortiz (1997, p. 249) were concerned that a preoccupation with Christ-figures could "distort any resulting theological insight" which a film might have contained prior to the neo-Procrustean exercise of Christ-figure hunting. Not surprisingly, there is also the issue of symbolism fatigue settling in that may lead to symbolism cynicism.

\subsection{From Symbolism Fatigue to Symbolism Cynicism}

Christ symbol hunting is so pervasive today that it can sometimes lead to viewer fatigue as evidenced within the religious literature; especially amongst evangelical Christians. For example, the mysterious online critic Leif H (1999) reviewed The Matrix (1999) and declared that the film was a techno-warfare passion narrative and annoyingly claimed:

This movie is so chock full of obvious Christian symbolism you could choke on it:...the biblical names like the heroine, Trinity [Carrie-Anne Moss], who loves our messiah back to life...I could write about the John the Baptist...The Peter figure, Morpheus [Laurence Fishburne], who looks for/believes-in the messiah...the very obvious Judas figure, Cypher [Joe Pantoliano], who didn't want to take the risk of believing that Neo [Keanu Reeves] was "the one" and so he sold out to the agents (the religious leaders, the keepers of the rules) because he thought that simulated reality might be just as good...the messiah figure, Neo [Keanu Reeves], and how he had to be incarnate in the matrix, how he was chosen, how he supposedly laid down his life, and how he came back to life to triumph. But these and other allusions (Zion, Babylon, and others) seems obvious, and there are some ones [sic] that are far more interesting to me. In talking to other Christians...The majority of them were enthusiastic about it, even enough to call it "A parable of the Gospel in modern-day language" (God have mercy) (para. 1-2) [my emphasis].

The religion-and-film community and multiple evangelicals quickly understood when "Neo became the image of Jesus: digital iconography" (Milford, 2010, p. 24); especially since:

It was no accident that The Matrix [1999] was released on an Easter weekend. There are numerous Christian motifs in the film, some obvious and others quite subtle. Most clear is the theme of the promised deliverer. In the Gospels, Jesus is the promised Messiah, the one "who is to come" (Luke 7:19 [BBE]). In the film, Neo is "the One," the messianic deliverer 
whose coming was foretold by the Oracle. "Neo" is an anagram for "one." Moreover, in Greek neo means "new," signifying the new life into which the risen Neo enters and which, presumably, he will make possible for others (Bassham, 2003, p. 111).

In short, the film was viewed as an audiovisual New Testament for a new millennium; despite its complex allegorical nature and polysemic imagery allowing one the freedom to alternatively view "The Matrix through the lens of Gnosticism, Berkeley's metaphysics, Buddhism, Pythagorean numerology, Neoplatonism, and, no doubt, countless other ideological viewpoints" (Fontana, 2003, p. 214).

Similar symbolism fatigue was also demonstrated by Christian film critic Peter Manseau (2001) who testily confessed:

You know the drill: The Matrix [1999] dresses Keanu Reeves up like a eurotrash seminarian, calls him "Neo" and hopes we'll buy him as the new New Adam. The Green Mile [1999] tells the story of death row inmate John Coffey [Michael Clarke Duncan] (J.C., get it?): "Like the Lord, but spelled different," he's Jesus too. In a similar grab for ever-allusive "meaning," The Beach [200o] kills off a character named Christoff [sic; Christo (Staffan Kihlbom)] for the sole purpose of pushing audiences to ponder, "Like, did that guy die for Leo's [Leonardo DiCaprio's (Richard's)] sins?" Nice try, but all it made me think was, Jesus Christ, enough already (para. 2) [my emphasis].

Other commentators progressed from symbolism fatigue to symbolism cynicism. For example, the eponymously named Mr. Crank! (1995) reviewed Braveheart (1995) and bitterly complained about its execution scene (see Figure 9) wherein:

...a really long and protracted moment where the camera lovingly dotes on Mel Gibson [playing William Wallace] as he is taken to a platform to be tortured. It's the kind of moment that makes preschoolers point to the screen and say, "Christ figure! Christ figure!" Either that or: "Look! He's shamelessly grooming himself for the Oscars!" (Oscar committees love Christ figures.) (npn) [my emphasis].

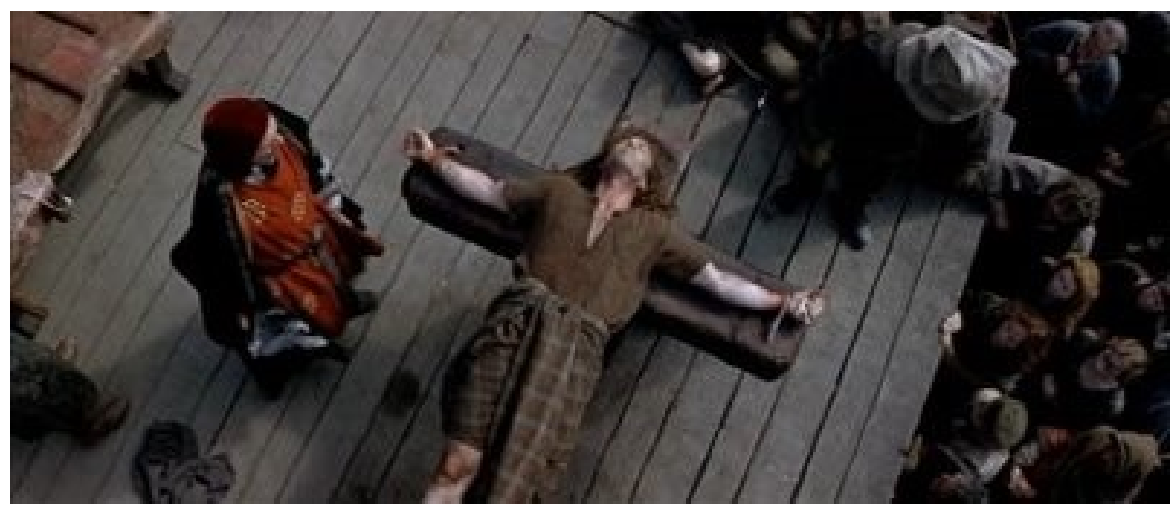

Figure 9: The cruciform William Wallace (Mel Gibson)

The Oscar grab is a logical possibility for this conservative Christian director, but does the Christian masochism in any way diminish the potency of the Christic iconography or devalue the power of its subtextual narrative; especially if the crucified Christ mise-en-scène was deliberately designed that way from the start? The author argues "No!" Indeed, Wallace's suffering upon his cross enhances the Christic subtext and would allow many more than Mr. Cranky's preschoolers to point to the screen and say, "Christ figure! Christ figure!" Especially considering that Wallace remains a pious Christian throughout the film, including times of adversity, he respectfully kneels 
to pray, and actively seeks God's guidance and help, just as Jesus did (Matt. 14:23; 26:39, 42, 44). As Kenneth Carr Hawley (1998) succinctly summed him up:

The film's version of William Wallace mirrors Christ in that he is of low birth, he disappears during adolescence only to return to the public eye during adulthood, he has a time of "ministry," he is betrayed by those closest to him, he suffers a "passion" at the hands of his accusers, and he dies for a cause that he seems destined to defend. In fact, Randall Wallace, the screenwriter for Braveheart [1995], is reported to have said that he blended the betrayal of Jesus by Judas with his version of Robert [the] Bruce's [Angus McFadyen's] treachery (p. 125).

Whilst William Wallace's Scottish clansman character thematically fitted in with "Braveheart's Rottweiler masculinity" (McArthur, 2003, p. 199).

\subsection{Pattern Appeasement: From Being Uncritical to Narrative Insights}

Having accepted the existence, viability, and the potential pedagogic usefulness of exploring-cumutilizing sacred subtexts, and after having dealt with the ten types of academic disquiet explicated above, an eleventh disquiet remains. Namely, succumbing to the trap of pattern appeasement that can lead to either satisfaction or misunderstanding of the filmic text. As Irena S. M. Makarushka (1999) argued:

It is tempting, as many critics have done, to read the character of Bess (Emily Watson) in Breaking the Waves [1996], a film written and directed by Lars von Trier, as yet one more Christ-figure, Mary Magdalene, or Joan of Arc. Fitting Bess neatly into these Christian literary conventions provides a replay of familiar paradigms and guarantees that the "natural" order of things will not be disrupted (p. 61) [my emphasis].

Therefore many media-aware Christians seek Christ-figure patterns within their filmic fare uncritically because it provides a modicum of personal comfort and security (whether religious, spiritual, psychological, or ideological) knowing that their hidden Jesus/God/divine messages reside within. ${ }^{\mathrm{x}}$ And especially if others still consider movies a pagan artform and therefore inherently prejudicial (Burnett \& Martell, 1932; Gilbert, 1942; Tozer, 1974), or a violation of the biblical prohibition against graven images (Exod. 20:4), or perceived merely as a waste of time better devoted to Bible-reading and studying their creedal literature.

Conversely, Christ-figure hunting can also provide viewers with narrative insights through plot predictability. How? Because once the subtextual Jesus has been established, one can comfortably predict what is likely to follow (e.g., betrayal, abuse, and death), ${ }^{x i i}$ and what was previously enigmatic is now understandable (e.g., the betraying friend is the Judas-figure!). Thus potentially encouraging pursuit of other biblical analogues in Jesus's diegetic life such as the John the Baptist-figure, Mary Magdalene-figure, Pontius Pilate-figure, Virgin Mary-figure etc. that may exist therein.

\section{The Begrudging Acceptance of the Sacred Subtext Enterprise}

Despite the above-explicated interpretative angst, distortions, contortions, and other challenging permutations, not unexpectedly, some commentators who were initially opposed to the sacred subtext enterprise eventually found it valuable and begrudgingly accepted it. For example, Christian film critic James Wall (1983) reviewed John R. May and Michael Bird's Religion in Film 
and was irritated by the enthusiastic religious reception of the child-focused SF film, E.T., the Extra-Terrestrial (1982). As he argued:

This is not a book for those who consider film a mere sociological medium, revealing human foibles and fantasies; nor is it for the preacher-mentality which awaits eagerly for screen analogues to bolster shaky theology of the cross and/or resurrection. These are not authors who will salivate over the arrival of E.T. [voice of Pat Welsh] because the little outerspace creature has enough parallels to Jesus to serve as sermonic analogical underpinning for the Risen Christ...E.T. was a nice little (albeit expensive) movie that touched human responses because the extra-terrestrial was a modern-day Lassie, wise in its own way, helpful to a boy's growing-up process, and vulnerable to the dangers of an adult world. And yet many sermons preached on E.T. wanted desperately to link it with the story of Jesus. For shame! (p. 370) [my emphasis].

And yet, E.T.'s subtextual parallels to Jesus far exceeded the veterinary parallels to Lassie (Short, 1983; Tomasulo, 2001)!

Later, Wall (1985) embraced E.T. (and Christian symbol hunting) when he nominated the adult-focused SF film Starman (1984) on his list of top fifteen films for 1984. It starred an alien, "Starman" (Jeff Bridges), who had responded to Earth's message of peace-cum-invitation found in the golden phonograph record installed on the Voyager 2 space probe. Initially a floating ball of glowing energy, when his scout vessel is shot down by the US government, he clones a human body (see Figure 10), and has some earthly adventures including miraculously resurrecting a dead deer and Jenny Hayden (Karen Allen) before slowly dying himself. At film's end he is instantly restored to health by a rescuing spherical spaceship and returns to his home in the stars (Ruppersburg, 1987; 1990). James Wall (1985, p. 92) now saw "Jeff Bridges [Starman] as an E. T. character who closely resembles a "gospel" figure because he is human and more than human at the same time," just like the hypostatic union of Jesus-two natures (human and divine) unified in one body. ${ }^{\text {xii }}$

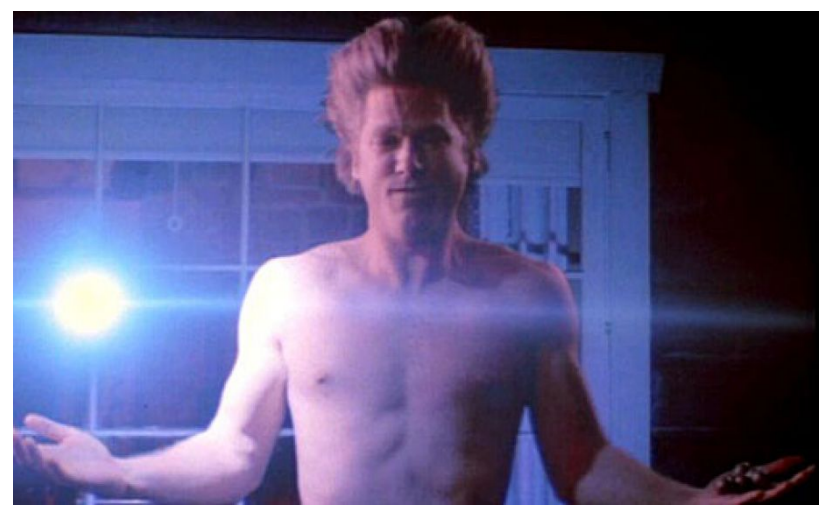

Figure 10: The Starman's cloned body (Jeff Bridges)

Much later, James Wall also embraced the naive seaman, William "Billy" Budd (Terence Stamp) in the $18^{\text {th }}$-century British Navy film, Billy Budd (1962), whom he considered was "a Christlike figure though without the wisdom of the original" (Wall, 200o, p. 34). Budd is young and beautiful who displayed simplicity, humility, and optimism, but like Jesus, he is betrayed, falsely accused (of planning a mutiny), and although totally innocent, he is judged guilty by Captain Vere (Peter Ustinov), "the Pontius Pilate of this Passion" (Warwick, 1990, p. 136). Budd is subsequently condemned to hang, and akin to Jesus's crucifixion cry: "Father, forgive them; for they know not what they do" (Luke 23:34), Billy Budd's last words were: "God bless Captain Vere!" which 
Ustinov-as-director did to "dramatize the greatest of Christian virtues, that of forgiveness" (Ustinov, 1997, p. 228).

\section{Conclusion}

Being cognizant of the inherent dangers and sources of academic disquiet is a valuable means of expanding one's visual and intellectual imagination, even if encountered in its via negativa form. Furthermore, it is also of practical value for the postmodern church itself for as Father Peter Malone (1997) argued:

Christ-figures and antichrist-figures in the arts, literature, theatre, television drama and cinema can be (whether they are derived from faith or from culture) key images in making the Gospels and the church credible, [thus] a contemporary means of apologetics (p. 71) [my emphasis].

After all, as Jesus Christ commanded (albeit, in a different context): "What I tell you in darkness, that speak ye in light: and what ye hear in the ear, that preach ye upon the housetops (Matt. 10:27). And so why would $21^{\text {st }}$ century scholars not choose to employ movies in the "Age of Hollywood" (Paglia, 1994, p. 12) during this current reign of moving image culture in our increasingly post-print, post-Millennial society? Further research into the subtextual sub-genre of the religion-and-film field is encouraged, warmly recommended, and is already long overdue. ${ }^{\text {iv }}$

\section{Notes}

i. The terms "Christ-figure," "Christ-figures" and other sacred subtexts identified herein will be treated as nouns and not adjectives.

ii. The author could not determine if the first three videos were mock or mainstream Mormon proselytizing media, but will assume the latter for convenience sake.

iii. Conversely, Michael Forest (2020, p. 302) claimed as much within John Ford's Stagecoach (1939): "After childbirth, Dallas [Claire Trevor] braids Lucy Mallory's [Louise Platt's] hair and cares for the baby. Mallory sees Dallas for the first time, a revelation of Dallas herself and a clear film evocation of the prostitute as Christ figure."

iv. Earlier versions of these arguments appeared in Kozlovic (2016).

v. Regrettably, this two-part online reference has now become a dead link, and so the page and paragraph numbers are no longer available.

vi. Whether it was done subconsciously, or as an unaware consequence of mimicking a legitimate sacred subtext, is of course a different matter.

vii. The actual words spoken in the film were: "Jesus! I hope it isn't political!"

viii. The King James Version of the Bible (KJV) will be referenced throughout (unless quoting other translations) because it is deeply embedded within Western culture and widely used worldwide (Taylor, 1992, ix, 71). 
ix. Interestingly, this feature hints at a post-Christianity metamorphosing into a parallel Christianity that readily accepts the fusion of sound and image, text and screen, as both normal and their cultural birth right.

x. Many large, white, purebred Yorkshire pigs played Babe.

xi. Akin to viewing films to assist emotional healing, role-modelling, and psychological transformation (Wolz, 2004).

xii. Albeit, given the paucity of biblical knowledge today (whether as religion, literature, or history), some viewers may be unsure of its storylines, as delightfully depicted in Jesus of Montreal (1989). Daniel Coulombe (Lothaire Bluteau) plays Christ hanging upon his cross in a theatrical reenactment when Security stops the play prematurely and directs the audience to leave. When a woman cries out: "Let them finish," "I want to see the end," an exasperated security guard (Gaston Lepage) replies: "Look, he dies on the cross and is resurrected. No big deal. Talk about slow!"

xiii. Furthermore, as Christopher W. Skinner (2015, p. 69) elaborates: "The story of Starman shares many similarities with John's presentation of Jesus: in like manner Jesus has come from above (1:1-2) and taken on human flesh (1:14); his mission is to complete the tasks assigned to him by the Father and return to the place from which he came (e.g., 14:1-6); when Jesus speaks he introduces alien concepts and utters enigmatic sayings that are all-to-often misunderstood by his audiences, who presume he is from Galilee (e.g., 7:52), and find his words difficult to accept (e.g., 6:6o-66; 10:31-33). This Jesus is not the gritty, earthy, Synoptic preacher of parallels from rural Galilee. He is rather a stranger from heaven, who consistently speaks about things above while mystifying his hearers."

xiv. I would like to thank Prof. Sean Redmond (Deakin University) and Dr. Toija Cinque (Deakin University) for their helpful suggestions for the improvement of this work.

\section{References}

Aichele, G. (2002). Foreword. In L. J. Kreitzer, Gospel images in fiction and film: On reversing the hermeneutical flow (pp. 7-10). London: Sheffield Academic Press.

Allen, S. (2013). Cinema, pain and pleasure: Consent and the controlled body. New York, NY: Palgrave Macmillan.

Ardolino, F. (1995). Born is the savior of baseball: Babe Ruth as Christ-figure in The Babe Ruth Story. Aethlon, 12(2), 87-93.

Balstrup, S. K. (2020). Spiritual sensations: Cinematic religious experience and evolving conceptions of the sacred. London: Bloomsbury Academic.

Barnett, P. C. (2000). Reviving cyberpunk: (Re)Constructing the subject and mapping cyberspace in the Wachowski brothers' film The Matrix. Extrapolations, 41(4), 359-374.

Bassham, G. (2003). The religion of The Matrix and the problems of pluralism. In William Irwin (Ed.), The Matrix and philosophy: Welcome to the desert of the real (pp. 111-125). New York, NY: PerfectBound.

Baugh, L. (1997). Imaging the divine: Jesus and Christ-figures in film. Kansas City: Sheed and Ward.

Baxter, J. (1985). Max's road: Some structures in the films Mad Max and Mad Max 2. In J. Blackford, R. Blackford, L. Sussex, \& N. Talbot (Eds.), Contrary modes: Proceedings of the world science fiction conference, Melbourne, Australia, 1985 (pp. 105-121). Melbourne: Ebony Books/Department of English, University of Newcastle. 
Beavis, M. A. (2010). Jesus of Canada? Four Canadian constructions of the Christ figure. In E. M. Leonard \& K. Merriman (Eds.), From logos to Christos: Essays on Christology in honour of Joanne McWilliam (pp. 19-38). Waterloo, ON: Wilfrid Laurier University Press.

Bechtold, J. (2015). Jesus in the cinema: The misrepresentation of the Christ-figure in popular film. In S. B. Murray \& A. U. Light (Eds), God and popular culture: A behind-the-scenes look at the entertainment industry's most influential figure. Volume 1 (pp. 99-114). Santa Barbara, CA: Praeger.

Becker, A. (1994). Review: Saint Paul at the movies: The apostle's dialogue with American culture - Robert Jewett. Trinity Seminary Review, 16(2), 116-117.

Blake, R. A. (1995). Woody Allen: Profane and sacred. Lanham, MD: The Scarecrow Press.

Blake, R. A. (1996). Converts. America, 175(8), 32-33.

Boer, R. (1995). Christological slippage and ideological structures in Schwarzenegger's Terminator. Semeia, 69/70, 165-193.

Bowman, D. (2001). Faith and the absent Savior in Central Station. The Journal of Religion E Film, 5(1). Available online at: https://digitalcommons.unomaha.edu/cgi/viewcontent.cgi?article=1792\&context=jrf (accessed 21 July 2020).

Boyd, M. (1962). The image of man: Criterion for a religious movie. In F. Eversole (Ed.), Christian faith and the contemporary arts (pp. 152-158). New York: Abingdon Press.

Bridge, J. D. (1994). Review: The New Testament in fiction and film: On reversing the hermeneutical flow Larry J. Kreitzer. Epworth Review, 21(3), 111-112.

Brill, L. (1988). The Hitchcock romance: Love and irony in Hitchcock's films. Princeton, NJ: Princeton University Press.

Burnett, R. G., \& Martell, E. D. (1932). The Devil's camera: Menace of a film-ridden world. London: The Epworth Press.

Bywater, T., \& Sobchack, T. (1989). An introduction to film criticism: Major critical approaches to narrative film. New York: Longman.

Capon, R. F. (2003). Genesis, the movie. Grand Rapids, MI: William B. Eerdmans.

Casebier, A. (1976). Film appreciation. New York: Harcourt Brace Jovanovich.

Chase, D. (1996). Review: Screening the sacred: Religion, myth, and ideology in popular American film - Joel W. Martin \& Conrad E. Ostwalt Jr. Journal of American Studies, 30(2), 327-328.

Christoforidis, V. (2014). The revelation of the Kryptonian Christ-figure: The greatest story ever retold? MDiv thesis: Concordia Lutheran Theological Seminary.

de Bleeckere, S. (1997). The religious dimension of cinematic consciousness in postmodern culture. In J. R. May (Ed.), New image of religious film (pp. 95-110). Kansas City: Sheed \& Ward.

Deacy, C. R. (1999). Screen Christologies: An evaluation of the role of Christ-figures in film. Journal of Contemporary Religion, 14(3), 325-337.

Dean, B. O. (2016). "Look up in the sky:" Superman as lived religion in contemporary American culture. $\mathrm{PhD}$ thesis: The University of Iowa.

Delalis, G. (1993). Bad Lieutenant. In F. N. Magill (Ed.), Magill's cinema annual 1993: A survey of the films of 1992 (pp. 44-48). Englewood Cliffs, NJ: Salem Press.

Ellis, R. (2001). Movies and meaning. The Expository Times, 112(9), 304-308. 
Faber, A. (2003). Redeeming sexual violence? A feminist reading of Breaking the Waves. Literature E Theology, 17(1), 59-75.

Flannery-Dailey, F., \& Wagner, R. L. (2004). Stopping bullets: Constructions of bliss and problems of violence. In M. Kapell \& W. G. Doty (Eds), Jacking in to the Matrix franchise: Cultural reception and interpretation (pp. 97-114). London: Continuum.

Fontana, P. (2003). Finding God in The Matrix. In G. Yeffeth (Ed.), Taking the red pill: Science, philosophy and religion in The Matrix (pp. 189-219). Chichester: Summersdale.

Ford, J. L. (200o). Buddhism, Christianity, and The Matrix: The dialectic of myth-making in contemporary cinema. Journal of Religion \& Film, 4(2). Available online at:

https://digitalcommons.unomaha.edu/cgi/viewcontent.cgi?article=1807\&context=jrf (accessed 22 July 2020).

Forest, M. (2020). Emerson's vision of America in John Ford's Stagecoach. Aesthetic Investigations, 3(2), 284-310.

Fraser, P. (1998). Images of the passion: The sacramental mode in film. Westport, CT: Praeger.

Frost, M. (2019, August 12). Stealth Messiahs: Christ figures in film. Mike Frost. Available online at: https://mikefrost.net/stealth-messiahs-christ-figures-in-film/ (13 July 2020).

Gallagher, M. P. (1997). Theology, discernment and cinema. In J. R. May (Ed.), New image of religious film (pp. 151-160). Kansas City: Sheed \& Ward.

Geck, J. A. (2020). Corpus Christi, corpus cyborgensis, and the body politic: The passion play of RoboCop. The Journal of Religion and Popular Culture, 32(1), 65-80.

Gilbert, D. (1942). Hell over Hollywood: The truth about the movies ( $3^{\text {rd }}$ ed.). Grand Rapids, MI: Zondervan.

Good, L. (1998a, March 2). An interpretation of Twelve Monkeys. Available online at: http://www.unc.edu/ goodness/12_monk.html (accessed 8 August 2015) [now a dead link].

Good, L. (1998b, March 2). An interpretation of Twelve Monkeys - continued -. Available online at: http://www.unc.edu/ goodness/12_monk2.html (accessed 8 August 2015). [now a dead link].

Hasenberg, P. (1998). Pain and redemption: Images of Jesus Christ in the films of Abel Ferrara. In G. Larcher, F. Grabner \& C. Wessely (Eds.), Visible violence: Sichtbare und verschleierte gewalt im film (pp. 59-76). Munster: Lit Verlag.

Hawley, K. C. (1998). The re-making of a mythic hero: Scottish nationalism in Braveheart. MA thesis: Texas Tech University.

Heath, S. (1998). God, faith and film: Breaking the Waves. Literature E Theology, 12(1), 93-107.

Ho, J. B. (2003). The Matrix: Using American popular film to teach concepts of Eastern mysticism in the college classroom. In J. Xing \& L. R. Hirabayashi (Eds), Reversing the lens: Ethnicity, race, gender, and sexuality through film (pp. 197-211). Boulder, CO: University Press of Colorado.

Hurley, N. P. (1982). Cinematic transfigurations of Jesus. In J. R. May \& M. Bird (Eds.), Religion in film (pp. 61-78, 231-232). Knoxville: The University of Tennessee Press.

Jasper, D. (1997). On systematizing the unsystematic: A response. In C. Marsh \& G. Ortiz (Eds.), Explorations in theology and film: Movies and meaning (pp. 235-244). Oxford: Blackwell.

Knauss, S. (2020). Religion and film: Representation, experience, meaning. Leiden: Koninklijke Brill NV.

Kozloff, S. R. (1981). Superman as saviour: Christian allegory in the Superman movies. Journal of Popular Film and Television, 9(2), 78-82.

Kozlovic, A. K. (2002a). Superman as Christ-figure: The American pop culture movie Messiah. Journal of Religion \& Film, 6(1). Available online at: 
https://digitalcommons.unomaha.edu/cgi/viewcontent.cgi?article=1771\&context=jrf (accessed 9 July 2020).

Kozlovic, A. K. (2002b). The holy, non-Christic biblical subtexts in Superman: The Movie (1978) and Superman II (1981). Journal of Religion and Film, 6(2). Available online at: https://digitalcommons.unomaha.edu/jrf/vol6/iss2/5/ (accessed 9 July 2020).

Kozlovic, A. K. (2003). The unholy biblical subtexts and other religious elements built into Superman: The Movie (1978) and Superman II (1981). Journal of Religion and Film, 7(1). Available online at: https://digitalcommons.unomaha.edu/cgi/viewcontent.cgi?article=1736\&context=jrf (accessed 9 July 2020).

Kozlovic, A. K. (2004). The hidden Jesus within popular films: Christ-figures as sacred subtexts. Scriptura: International Journal of Bible, Religion and Theology in Southern Africa, 85, 97-109.

Kozlovic, A. K. (2005). Jesus covered in a secular wrapper: The Christ-figure in popular films. Kinema: A Journal for Film and Audiovisual Media, 24(Fall), 33-54.

Kozlovic, A. K. (2016). Some complaints, qualms, and (in)credulity issues concerning cinematic Christfigures. Kinema: A Journal for Film and Audiovisual Media, 46(Fall), 29-58.

Lacy, T. (2014). Christian torture porn: The violent passion of Mel Gibson. Society for U.S. Intellectual History, 12 December. Available online at: https://s-usih.org/2014/12/christian-torture-porn/ (accessed 22 June 2020).

Leif H. (1999). Movie review: The Matrix. Viewer comments. Christian Spotlight on Entertainment. Available online at: http://christiananswers.net/spotlight/movies/prezooo/i-thematrix.html (accessed 1o June 2020).

Lofficier, R., \& Lofficier, J.-M. (1985). Terry Hayes: Creating the "Mad Max" myth. Starlog 99 (October), 1518.

Lyons, D. (1992). Scumbags. Film Comment, 28(6), 6, 8.

Mabry, J. R. (1999). The Gnostic generation: Understanding and ministering to generation X. Presence: The Journal of Spiritual Directors International, 5(2), 35-47.

Makarushka, I. S. M. (1999). Transgressing goodness in Breaking the Waves. In S. B. Plate \& D. Jasper (Eds.), Imag(in)ing otherness: Filmic visions of living together (pp. 61-80). Atlanta, GA: Scholars Press.

Malone, P. (1988). Movie Christs and antichrists. Eastwood, NSW: Parish Ministry Publications.

Malone, P. (1990). Jesus of Montreal. Compass: A Review of Topical Theology, 24(4), 40-42.

Malone, P. (1997). Jesus on our screens. In J. R. May (Ed.), New image of religious film (pp. 57-71). Kansas City: Sheed \& Ward.

Malone, P. (2012). Christ-figures in cinema, in religion, in theology. Compass: A Review of Topical Theology, 46(3), 19-26.

Manseau, P. (2001). Hannibal Lecter's harrowing of hell. Killing the Buddha, 16 February. Available online at: http://killingthebuddha.com/mag/exegesis/hannibal-lecters-harrowing-of-hell-2/ (accessed 10 June 2020).

Marsh, C. (2005). Cinema and sentiment: Film's challenge to theology. Milton Keynes: Paternoster.

Marsh, C., \& Ortiz, G. (1997). Theology beyond the modern and the postmodern: A future agenda for theology and film. In C. Marsh \& G. Ortiz (Eds.), Explorations in theology and film: Movies and meaning (pp. 245-255). Oxford: Blackwell.

Martin, J. W., \& Ostwalt Jr., C. E. (Eds.). (1995). Screening the sacred: Religion, myth, and ideology in popular American film. Boulder: Westview Press. 
Marty, J. (1997). Toward a theological interpretation and reading of film: Incarnation of the word of God relation, image, word. In J. R. May (Ed.), New image of religious film (pp. 131-150). Kansas City: Sheed \& Ward.

May, J. R. (1997). Contemporary theories regarding the interpretation of religious film. In J. R. May (Ed.), New image of religious film (pp. 17-37). Kansas City: Sheed \& Ward.

McArthur, C. (2003). Brigadoon, Braveheart and the Scots: Distortions of Scotland in Hollywood cinema. New York, NY: I. B. Taurus.

McBride, J. (2006). What ever happened to Orson Welles?: A portrait of an independent career. Lexington, KY: The University Press of Kentucky.

McEntyre, M. C. (2012). Christ, my companion: Meditations on the Prayer of St. Patrick. Eugene, OR: Wipf and Stock Publishers.

McEver, M. (1998). The messianic figure in film: Christology beyond the biblical epic. The Journal of Religion E Film, 2(2). Available online at: https://digitalcommons.unomaha.edu/jrf/vol2/iss2/3/ (accessed 8 August 2015).

Mercadante, L. (2001). Bess the Christ figure?: Theological interpretations of Breaking the Waves. Journal of Religion and Film, 5(1). Available online at:

https://digitalcommons.unomaha.edu/cgi/viewcontent.cgi?article=1795\&context=jrf (accessed 1 August 2020).

Milford, M. (2010). Neo-Christ: Jesus, The Matrix, and secondary allegory as a rhetorical form. Southern Communication Journal, 75(1), 17-34.

Mr. Cranky! (1995). Braveheart. http://www.mrcranky.com/movies/braveheart.html (accessed 8 August 2015) [now restricted access].

Ortiz, G. (1994). Jesus at the movies: Cinematic representations of the Christ-figure. The Month, 27(12), 491497.

Paglia, C. (1994). Vamps and tramps: New essays. New York: Vintage Books

Peavy, C. D. (1974). The secularized Christ in contemporary cinema. Journal of Popular Film, 3(2), 139-155.

Pomeroy, D. W. (1974). Theological table-talk: 1973-year of the religious film. Theology Today, 31(1), 47-49.

Rebolledo, F. (2005). Central do Brasil (Central Station): Coconut milk with Coca-Cola aftertaste. In the wake of Cinema Nôvo. Off Screen, 9(6). Available online at: https://offscreen.com/view/central_brasil (accessed 21 July 2020).

Reinhartz, A. (2008). Playing with paradigms: The Christ-figure genre in contemporary film. Australian Religion Studies Review, 21(3), 298-317.

Reinhartz, A. (2011). Jesus and Christ-figures. In J. Lyden (Ed.), The Routledge companion to religion and film (pp. 420-439). London: Routledge.

Revington, R. (2018). Crisis on infinite texts: How Superman developed into a Jesus figure. MA thesis: McMaster University.

Ruppersburg, H. (1987). The alien Messiah in recent science fiction films. Journal of Popular Film \& Television, 14(4), 158-166.

Ruppersburg, H. (1990). The alien Messiah. In A. Kuhn (Ed.), Alien zone: Cultural theory and contemporary science fiction film (pp. 32-38). London: Verso.

Scully, M. (1997). The message of film 5: Jesus in modern media. Milwaukee, WI: Hi-Time Publishing.

Seesengood, R. P., \& Walsh, R. (2018). There's a new Messiah in town: The messianic in the western. In R. Walsh (Ed.), TET Clark companion to the Bible and film (pp. 248-259). London: T\&T Clark. 
Sherwin, J. (1999). Quotable Star Trek. New York: Pocket Books.

Short, R. (1983). The Gospel from outer space. London: Collins/Fount Paperbacks.

Skinner, C. W. (2015). Reading John. Eugene, OR: Cascade Books.

Staley, J. L. (2016). Martin Scorsese's Aviator as theological complement to his Last Temptation of Christ." In L. Copier and C. V. Stichele (Eds.), Close encounters between Bible and film: An interdisciplinary engagement (pp. 233-249). Atlanta, GA: SBL Press.

Stoffel, T. (1998, November 22). The lion of Judah and the king of pride rock: An overview of Christian principles in Disney's 'The Lion King.' Available online at: http://www.lionking.org/text/Judah-TS.txt (accessed 16 July 2020).

Taylor, M. D. (1992). The complete book of Bible literacy. Wheaton, IL: Tyndale.

Taylor, S. J. (2003) 'It all happens here:' Locating salvation in Abel Ferrara’s Bad Lieutenant. Journal of Religion \& Film, 7(1). Available online at:

https://digitalcommons.unomaha.edu/cgi/viewcontent.cgi?article=1747\&context=jrf (accessed 21 July 2020).

Telotte, J. P. (2001). Science fiction film. Cambridge: Cambridge University Press.

Telford, W. R. (2000). Religion, the Bible and theology in recent films (1993-1999). Epworth Review, 4, 31-40.

Tomasulo, F. P. (2001). The gospel according to Spielberg in E.T.: The Extra-Terrestrial. Quarterly Review of Film and Video, 18(3), 273-282.

Tozer, A. W. (1974). Menace of the religious movie. Wisconsin Rapids, WI: Rapids Christians.

Ustinov, P. (1977). Dear me. London: Heinemann.

Vaidyanathan, T. G. (1996). Hours in the dark: Essays on cinema. Delhi: Oxford University Press.

Wall, J. M. (1983). Review: Religion in film - John R. May \& Michael Bird. Theology Today, 4o(3), 368, 370371.

Wall, J. M. (1985). Editorials: Lean film leads year's top ten. The Christian Century, 102(4), 91-92.

Wall, J. M. (2000). Screening ambiguity: From conflict to the common good. Media Development, 47(4), 3335 .

Walsh, R. (2013). A modest proposal for Christ-figure interpretations: Explicated with two test cases. Relegere: Studies in Religion and Reception, 3(1), 79-97.

Warwick, C. (1990). The universal Ustinov. London: Sidgwick \& Jackson.

Wolz, B. (2004). E-motion picture magic: A movie lover's guide to healing and transformation. Centennial, CO: Glenbridge.

Worthing, M. W. (2004). The Matrix revealed: The theology of the Matrix trilogy. Millswood, SA: Pantaenus Press.

\section{Filmography}

A Farewell to Arms (1932, dir. Frank Borzage)

American Beauty (1999, Sam Mendes)

Babe (1995, dir. Chris Noonan)

Babe, Pig in the City (1998, dir. George Miller)

Baby Doll (1956, dir. Elia Kazan) 
Bad Lieutenant (1992, dir. Abel Ferrara)

Ben Hur (aka Ben-Hur: A Tale of the Christ) (1959, dir. William Wyler)

Billy Budd (1962, dir. Peter Ustinov)

Braveheart (1995, dir. Mel Gibson)

Breaking the Waves (1996, dir. Lars von Trier)

Cape Fear (1991, dir. Martin Scorsese)

Central Station (aka Centro do Brasil) (1998, dir. Walter Salles)

Conan the Barbarian (1982, dir. John Milius)

Dark City (1998, dir. Alex Proyas)

David and Bathsheba (1951, dir. Henry King)

E.T., the Extra-Terrestrial (1982, dir. Steven Spielberg)

Edward Scissorhands (1990, dir. Tim Burton)

Jesus Christ, Superstar (1973, dir. Norman Jewison)

Jesus of Montreal (1989, dir. Denys Arcand)

Jonathan Livingston Seagull (1973, dir. Hall Bartlett)

“Journey's End” episode of Star Trek: The Next Generation (1994, dir. Corey Allen)

Lo chiamavano Trinita (1971, dir. E. B. Clucher [Enzo Barboni]; They Call Me Trinity)

Looking for Jesus (aka Cercasi Gesu) (1982, dir. Luigi Comencini)

Mad Max (1979, dir. George Miller)

Mad Max 2 (aka The Road Warrior) (1981, dir. George Miller)

Mad Max Beyond Thunderdome (1985, dir. George Miller \& George Ogilvie)

Mad Max: Fury Road (2015, dir. George Miller)

Orgazmo (1997, dir. Trey Parker)

Pale Rider (1985, dir. Clint Eastwood)

Platoon (1986, dir. Oliver Stone)

Pulp Fiction (1994, dir. Quentin Tarantino)

Raging Bull (1980, dir. Martin Scorsese)

Samson and Delilah (1949, dir. Cecil B. DeMille)

Shane (1953, dir. George Stevens)

Shirley Valentine (1989, dir. Lewis Gilbert)

Solomon and Sheba (1959, dir. King Vidor)

Stage Coach (1939, dir. John Ford)

Starman (1984, dir. John Carpenter)

Superman: The Movie (aka Superman) (1978, dir. Richard Donner)

The Beach (200o, dir. Danny Boyle) 
31 One Danger and Eleven Types of Academic Disquiet Whilst Hunting for Cinematic Christ-figures

The Day the Earth Stood Still (1951, dir. Robert Wise)

The Good, the Bad, and the Ugly (1966, dir. Sergio Leonie)

The Green Mile (1999, dir. Frank Darabont)

The Informer (1935, dir. John Ford)

The Lion King (1994, dir. Roger Allers \& Rob Minkoff)

The Matrix (1999, dir. Andy \& Larry Wachowski)

The Matrix Revolutions (2003, dir. Andy \& Larry Wachowski)

The Omega Man (1971, dir. Boris Sagal)

The Passion of the Christ (2004, dir. Mel Gibson)

The Ten Commandments (1956, dir. Cecil B. DeMille)

The Terminator (1984, dir. James Cameron)

The Trial (aka Le procès) (1962, dir. Orson Welles)

The Truman Show (1998, dir. Peter Weir)

Twelve Monkeys (1995, dir. Terry Gilliam) 